\title{
COMMENT
}

\section{CORPORATE PRIVACY: A REMEDY FOR THE VICTIM OF INDUSTRIAL ESPIONAGE}

\author{
INTRODUCTION
}

Although the topic of industrial espionage ${ }^{1}$ has evoked a considerable discussion over the last several years, ${ }^{2}$ it has been an infrequent subject of litigation. ${ }^{3}$ For the most part the discussion of industrial espionage has concerned its effects and ramifications upon American industry, with generally little attention to the legal means by which its victims may seek relief. The means of seeking relief, however, have recently become a more popular subject of inquiry ${ }^{4}$ and has generated an impressive number of analyses and proposals. ${ }^{5}$ Proceeding upon the assumption that corporations should in fact be protected from the ravages of industrial espionage, this comment will analyze the present legal posture of the industrial espionage victim and suggest one means by which protection might be afforded. To put this discussion in perspective, the evolution of the several trends which

1. "Industrial espionage is the practice of engaging in surreptitious surveillance for the purpose of discovering a businessman's secrets." Comment, Industrial Espionage: Piracy of Secret Scientific and Technical Information, 14 U.C.L.A.L. REv. 911 (1967) [hereinafter cited as Industrial Espionage]. To be distinguished from industrial espionage are the normal intelligence activities lawfully practiced by most competitors. See generally Smith, Business Espionage, Fortune, May, 1956, at 118-20.

2. Considerable commentary exists on the ramifications and effects of industrial espionage on American industry. For a bibliography see 2 R. CALlmann, UNFair Competition, TradeMarKs, \& MONOPolies $\$ 56$ (3d ed. 1968) [hereinafter cited as Callmann]; R. Milgrim, Business Organizations, Trade Secrets $\S 5.05$ (1967) [hereinafter cited as Milgrim]; Industrial Espionage $911 \mathrm{n.2}$; Comment, Industrial Secrets and the Skilled Employee, 38 N.Y.U.L. Rev. 324, 326 (1963) [hereinafter cited as Industrial Secrets]. Such commentary has served the function of surveying the magnitude of the problem and analyzing the motivation that induces competitors to indulge in espionage activities. See Hearings on S. 928 Before the Subconm. on Administrative Practice and Procedure of the Senate Comm. of the Judiciary. 90th Cong., Ist Sess., pt. 2, at 551 (1967) [hereinafter cited as Hearings on S. 928].

Although prominent articles have appeared which discount the industrial espionage threat, see, e.g., Furasch, Industrial Espionage, HARv. Bus. Rev., Nov.-Dec., 1959, at 6, the sheer mass of material on the subject attests to its prominence in the business community.

3. Klein, The Technical Trade Secret Quadrangle: A Survey, 55 Nw. U.L. Rev. 437, 462 (1962) [hereinafter cited as Klein].

4. See Hearings on S. 928, at 610 (Report of the Invasion of Privacy Study Committee of the State of Georgia); Industrial Espionage 915-25. See notes 105-06 infra and accompanying text.

5. See notes 105-06 infra and accompanying text. 
have created a situation which demands a new remedy must be reviewed.

\section{The Privilege of Competitor Surveillance}

Since participation in a competitive economic system requires knowledge and information concerning the nature of competitor activity, the privilege of competition has always been thought to include the right to survey competitors for general market intelligence-for example, product characteristics, marketing plans, pricing policies, and manufacturing methods. ${ }^{6}$ Such a right, however, is subject to abuse, ${ }^{7}$ and the courts early assumed the task of monitoring its exercise. In fulfilling that duty, the courts sought to prevent abuses by prohibiting the use of those means of surveillance which would allow the acquisition of information not reasonably necessary for the promotion of competition. ${ }^{8}$

To serve this role as market referee, the courts were required to impose on competitors the constraints and incentives necessary for the facilitation of that mode of market conduct deemed beneficial by society-traditionally encouraging innovation and discouraging wrongful conduct. ${ }^{9}$ These goals were not contradictory since

6. "A competitor can and must shop his competitors for pricing and examine his products for quality, components, and methods of manufacture." E.I. duPont deNemours \& Co. v. Christopher, 431 F.2d 1012, 1016 (5th Cir. 1970), cert. denied, 400 U.S. 1024 (1971). Were it otherwise, the first person to make a discovery would have a monopoly. See Restatement of TORTS $\$ 757$, comment $a$ at 2 (1939).

The subject matter of industrial espionage covers different types of tangible and intangible, technical and non-technical information, and includes commercial secrets as well as operational information. The term commercial secrets refers to data which is subject to trade secret protection. See note 70 infra and accompanying text. Operational information, however, refers to data not subject to traditional trade secret protection although of equal value to businessmen and held in comparable secrecy. This distinction in the treatment of commercial secrets and operational information is an important reason for expanding the basis of relief available to the industrial espionage victim. See notes 136-37 infra and accompanying text. These two classes of information are discussed in detail in Note, Trade Secret Protection of Non-Technical Competitive Information, 54 lowa L. REv. 1164-67 (1969).

7. See 1 CallmanN $\S 1$.

8. See Peterson, The Legislative Mandate of Sears and Compco: A Plea for a Federal Law of Unfair Competition, 69 Dick. L. REv. 347, 348 (1965).

9. The discouragement of reprehensible business practices and the encouragement of innovational activity are said to insure economic growth. Water Servs., Inc. v. Tesco Chems., Inc., 410 F.2d 163, 172 (5th Cir. 1969). See also RestatEMENT of TORTs $\S 757$, comment $a$ (1939); Bender, Trade Secret Protection of Software, 38 GEo. WASH. L. REv. 909, 910, 924 (1970) [hereinafter cited as Bender]; Stedman, Trade Secrets, 23 OHı ST. L.J. 4, 31 (1962) [hereinafter cited as Stedman]; Note, Industrial Espionage-Nebraska's New Felony, 45 Neb. L. REv. 644 (1966).

These arc the same bases of the patent, copyright, and trademark laws. Sears, Rocbuck \& 
innovation was encouraged by affording the discoverer of a new idea a protected status by precluding his competitors from wrongfully discovering or using the idea. ${ }^{10}$ To implement those broad policy dictates, the common law evolved a series of rather amorphous trade secret and unfair competition doctrines which sought to protect the discoverer of commercial secrets, while at the same time allowing competitors enough latitude to exercise their traditional, and necessary, privilege of competitor surveillance. ${ }^{11}$ The essence of these doctrines was that the owner of a secret was protected against improper means of discovery, while the competitor retained the right to make use of proper means to discover the secret. ${ }^{12}$

Co. v. Stiffel Co., 376 U.S. 225, 229 (1964). The Constitution provides that: "The Congress shall have Power . . . To promote the Progress of Science. . . ." U.S. ConsT. art. I, § 8.

10. A protected status encourages innovation since during the secrecy of the discovery the discoverer has monopolistic power over its application and may exploit that position to recoup research costs and seek profits, hopefully before competition duplicates or reverse engineers the product. Water Servs., Inc. v. Tesco Chems., Inc., 410 F.2d 163 (5th Cir. 1969). See also ABA Section of Patent, Trademark \& Copyright Law Proceedings 174 (1969); Bender 924; Stedman 25.

Innovation is also said to be fostered by a policy favoring the dissemination of ideas, since disclosure promotes competition and makes possible an informed market where knowledge is applied to accelerate technological development. Stedman 31; Industrial Espionage 913-14. If dissemination is the goal, however, a protected status would still be preferable, since protection stimulates commercial exploitation through licensing. See Bender 924; 84 HaRv. L. Rev. 477, 482 (1970). All of these arguments are discussed in Note, Doctrine of Licensee Estoppel Overruled; State Protection of Unpatented Inventions Questioned-Lear, Inc. v. Adkins, 45 N.Y.U.L. Rev. 386, 392-93 (1970).

If protection is not provided, innovation will be discouraged by the competitive disadvantages of innovators who have not only lost their monopoly gestation period in which to recover costs and seek profits, but whose competitors have obtained the fruits of their research without corresponding development costs. See Bartenstein, Research Espionage: $A$ Threat to Our National Security, 17 Food Drug CoSM. L.J. 813, 820 (1962); Bender 910; Daniel, Spies Invade Big Business, ReAder's Digest, Jan., 1962, at 93, 97. See also MilgRim § 9.01; Developments in the Law-Competitive Torts, 77 HARv. L. REv. 888, 948 (1964) [hereinafter cited as Developments-Competitive Torts]; Industrial Espionage 913; Industrial Spying Goes Big Business, BUS. WeEK, Oct. 6, 1962, at 65.

11. This development originated in the "conscience, justice and equity of the common-law judges. [The doctrines] . . . developed . . . to deal with business malpractices offensive to the ethics of . . . society, [were] a persuasive example of the law's capacity for growth in response to the ethical, as well as the economic needs of society." Dior v. Milton, 9 Misc. $2 \mathrm{~d} 425,155$ N.Y.S.2d 443 (Sup. Cl.), aff d mem., 2 App. Div. 2d 879, 156 N.Y.S.2d 996 (1956). See also 1 H. Nims, UNFalR Compermion and TRADE-Marks $\$$ I (4th cd. 1947) [hereinafter cited as Nims]; Peterson, supra note 8, at 347-48.

12. This is the essence of the law of trade secrets. See notes 70-76 infra and accompanying text. 


\section{Competitive Pressure to Employ Improper Means of Discovery}

The extent to which competitors will seek to use or develop improper means of discovery is partially a function of competitive pressure in the market. ${ }^{13}$ At the time when trade secret law developed, the competitive nature of most markets was not particularly intense, simply as a consequence of their local nature, the lack of comparative knowledge by purchasers, and the more or less homogenous nature of competing products. As society became mobile and developed instantaneous mass communication, however, purchasers were made aware of the availability and relative merits of competing products, causing the nature of most markets to undergo marked change. ${ }^{14}$ Consumer knowledge, in turn, caused product differentiation and innovation to become the critical elements of competition and placed increasing pressure on businesses to develop competitive advantages..$^{15}$ To meet these demands often required an aggressive program of research and development to create the innovations required to differentiate one's own products from those of his competitors. As a consequence of the rapid acceleration of technological discovery, however, such a research program could be an extraordinarily difficult and costly undertaking. ${ }^{16}$

Thus, as technical evolution progressed and the competitive pressure in many product markets intensified, improper discovery of the commercial secrets of competitors became an attractive proposition. ${ }^{17}$ Faced with such pressure, business decision-makers had

13. See generally 1 CallmanN $\S 1$.

14. It could be argued specifically that as an industry departs from the purcly competitive model, the actions and strategies of competitors take on an increasingly important function in decision-making and risk reduction. See 54 lowa L. Rev., supra note 6, at 1164. For an example of the transition from the "old" to the "new" environment, see Industrial Secrets 32526.

15. Research secrets became the sine qua non of industrial power, and the company that did not have secrets to protect really was not competing. Bender 913 .

16. These increasing expenditures for research and development also encouraged industrial espionage. See 45 NeB. L. ReV., supra note 9, at 645.

17. Bartenstein, supra note 10 , at 820 . The pressure of an economic system where momenteous change is incipient is well illustrated by the following passage:

Neither ["talent for exasperation nor nostalgia"] can erase a company president's night

thoughts....

... when a competitor persuades the American Dental Association to love another toothpaste, or a company he thought was in the film coating business in upstate New York comes out with a dry-process office copier that makes his whole inventory . . . nothing more than a tax writeoff; or a rival drug company takes the hottest thing to come 
to ponder the fact that a competitor's advantage could be reduced or eliminated without the usually corresponding burden of staggering development costs if his technological secrets could be obtained. ${ }^{18}$ Even if he were to consider only the acquisition of operational intelligence, as opposed to technical research secrets, the decisionmaker could look forward to the satisfying prospect of knowing his competitor's strategy at nominal cost. ${ }^{19}$

\section{Availability of Electronic Surveillance}

At the same time that greater pressure was exerted upon competitors to engage in improper discovery, the ability to gather the commercial secrets of others increased. One of the unanticipated byproducts of World War II was a substantial advancement in both the equipment and techniques of electronic surveillance. These developments, originally intended for military espionage and counterespionage use ${ }^{20}$ enabled business competitors to penetrate the privacy of offices and monitor the basic channels of communication ${ }^{21}$ without the necessity of physical presence or the cooperation of disloyal confidants. ${ }^{22}$ The equipment used to carry out this surveillance was not only lawful to possess but readily available to the general public at reasonable prices. ${ }^{23}$ Moreover, scores of men

out of his laboratories, adds a molecule, and walks away with a good part of the market.

E. Engberg, The Spy in the Corporate Structure 129 (1967) [hereinafter cited as ENGBERG].

18. The competitor had to ask himself why he should expend the funds and energy necessary to successful research when it is apparent that another company has satisfactorily resolved his very problem. MILGRIM $\S 5.04[4]$; Bartenstein, supra note 10 , at 820 .

19. A competitor's actions or strategies often constitute a significant variable in the process of business decision-making. 54 lowa L. REV., supra note 6, at 1164. See also ENGBERg 263; Smith, supra note 1, at 118-20.

20. A. Westin, Privacy and Freedom 67 (1967) [hereinafter referred to as Westin]; Hearings on $S .92867,441$.

21. WESTIN 365 .

22. The availability of electronic devices enables the unfair competitor to obtain secrets not accessible to him before their development. Industrial Espionage 912.

23. E. Long, The INTRuders 64-78 (1966); Westin 365. These devices are often extraordinarily simple to use, and anyone with enough skill, patience, and spare time to assemble a jigsaw puzzle may install an effective eavesdropping system. ENGBERG 55-56. For further discussion of the methods and technology of eavesdropping, see Hearings on S. 928, pt. 1, 73-86; S. Dash, R. Schwartz, \& R. KNowlton, The Eavesdroppers 303-81 (1959); Runft, The Electronic Eavesdropping Threat to the Right of Privacy: Can the States Help?, 3 IDAHO L. REv. 13, 14-31 (1966); Westin, Science, Privacy \& Freedom: Issues and Proposals for the 1970's, 66 Colum. L. Rev. 1003, 1004-10 (1966).

It is increasingly common, however, to find that the mere possession of eavesdropping 
thoroughly trained by the military in the use of this sophisticated equipment were then reentering the private enterprise system. ${ }^{24}$ Therefore, the increased pressure to discover the commercial secrets of competitors coincided with the similarly increased procurement capability.

The conflation of need to know and ability to get, of course, soon led to utilization, and within a very few years, what had been the problem of wrongful competitor conduct became the pervading specter of industrial espionage..$^{25}$ Instead of the problem of coping with interpersonal or other readily apparent wrongs, the owner of commercial secrets now faced the surreptitious incursion of the techniques and gadgets of technological development, ${ }^{26}$ which had previously been generally associated only with international "cloakand-dagger" operations.

\section{COMMON LAW RESPONSE TO THE ENCROACHMENTS OF TECHNOLOGICAL SUR VEILLANCE}

The application of advanced surveillance technology was, of course, not limited to extracting business secrets -individuals as well as businesses became the targets of surreptitious surveillance. ${ }^{27}$ In the past, as a means of remedying the wrongs consequent upon the uses of

devices is a crime. See, e.g.; GA. CODE ANN. $§ 26-3003$ (Supp. 1970); MICh. Comp. Laws ANN. $\S 750.539$ (f) (1968); Minn. Stat. AnN. \$ 626A.03 (Supp. 1970); N.H. Rev. Stat. AnN. $\S$ 570-A:3 (Supp. 1970); N.Y. Penal Law $§ 250.10$ (McKinney 1967); R.1. GeN. Laws ANN. \$11-35-24 (Supp. 1969). This development has heen consistent with the opinion of Congressman Gallagher that there is a "need for a great deal of new legislation regarding many aspects of invasion of privacy. There may be a pressing need for some sort of control over the manufacture, distribution, and sale of electronic devices and other gadgets used for snooping. ..."Hearings Before a Subcomm. of the House Comm. of Government Operations, 89th Cong., Ist Sess., at 7 (Special Inquiry on Invasion of Privacy).

24. ENGBERG 191-96; Industrial Secrets 327.

25. Industrial espionage is generally deemed a function of three contemporary business facts: the high cost of research and development, a decrease in the usefulness of patents, and a shortage of qualified technicians. Levitan, Trade Secret Piracy, 14 Clev.-MaR. L. Rev. 157, 158-59 (1965); see Smith, supra note 1, at 120; Industrial Espionage 912. It is also described as a concomitant of a devotion to science. Industrial Secrets 326.

26. The motives and targets of business espionage perpetration may be many and varied, based either upon competitive or political considerations. Hearings on S. 928551.

27. The encroachment of technology upon the individual may be illustrated by the use of the camera which raised the initial proposal for a right of privacy. Warren \& Brandeis, The Right of Privacy, 4 HaRv. L. Rev. 193, 195 (1890) [hereinafter cited as Warren \& Brandeis]. Other examples may be the tapping of private telephone lines, Rhodes v. Graham, $238 \mathrm{Ky} .225,37$ S.W.2d 46 (Ct. App. 1931), and the use of electronic transmission devices by a landlord to overhear a tenant's conversations, Roach v. Harper, 143 W. Va. 869, 105 S.E.2d 564 (1956). 
the older commercial predatory techniques, the law had developed theories based upon contract, trust, and confidence, which were utilized to protect both the interests of the individual ${ }^{28}$ and the business entity. ${ }^{29}$ These doctrines provided expeditious remedies as long as the cause of action involved a contract upon which a term could be implied or a relationship upon which a trust or confidence could be engrafted. ${ }^{30}$ As technology evolved, however, the opportunity to perpetrate wrongs in circumstances outside contractual or fiduciary relationships abounded, vitiating the protective force of the traditional theories. ${ }^{31}$ Thus, to adequately protect the victims of technological encroachment required the creation of a remedy of much broader foundation. ${ }^{32}$

\section{Protection for the Individual}

The principal means of providing a place of sanctuary to the individual from the prying eyes and ears of an inquisitive societ ${ }^{33}$ was through the evolution of the law of privacy, accelerated by an article in the Harvard Law Review by Samuel Warren and Louis Brandeis, ${ }^{34}$ which was written in specific fulmination against the photographic surveillance of Warren's family carried on by the "yellow press." 35 The article's analysis is predicated upon the inadequacy of traditional doctrine to handle the new "technological wrongs" and a consequent search for protection therefrom. Warren and Brandeis noted that the law had evolved over time in response to new threats as they confronted the individual. Initially he was accorded physical protection against restraint and injury. Then the law of nuisance evolved to protect his human sensibilities, and the doctrines of libel

28. Warren \& Brandeis 207-12.

29. 2 CallmanN $\S 5 \mathrm{I}$; Restatement of ToRTs $\S 757$, comment $a$ (1939); Klein 440; Stedman 22-24; Warren \& Brandeis 212.

30. Warren \& Brandeis 210 . See also 2 Callmann $\S 51$; Restatement of Torts $\$ 757$, comment $a$ at 4 (1939).

31. Warren \& Brandeis 210-11; see Nizer, The Right of Privacy: A Half Century's Developments, 39Mich. L. REv. 526, 559 (1941).

32. Warren \& Brandeis 211.

33. Id. at 197.

34. Id.' at 193. The actual origination of the right of privacy should probably be attributed to Judge Cooley who had earlier noted that there was a "right to be let alone." T. COoLEY, TORTS 29 (2d ed. 1888). The development of this right of privacy has been criticized. Kalven, Privacy and Tort Law-Were Warren and Brandeis Wrong?, 31 LAW \& ContEMP. ProB. 326 (1966).

35. Prosser, Privacy, 48 Calif. L. Rev. 383-84 (1960). 
and slander arose to protect his external reputation. ${ }^{36}$ Rather than finding a right of privacy in the maxims of equity or in natural law theory, Warren and Brandeis preferred the legally more concrete approach of analogy. Principal support for their right of privacy was found in the common law doctrines of intellectual and artistic property. ${ }^{37}$ These doctrines were determined not to be based upon principles of contract or trust but instead to be instances and applications of a general right of privacy. ${ }^{38}$ Since the right of privacy had already been recognized, Warren and Brandeis concluded that the law could protect the individual from advancing technology without formulating a new legal principle ${ }^{39}$-a position soon adopted by the courts. ${ }^{40}$

In anticipation of a discussion of the privacy principle in a commercial context, it is significant to note that in the process of reaching their conclusion that the law already afforded privacy protection, Warren and Brandeis observed that the law of trade secrets $^{41}$ was another aspect of intellectual property whose basis was identified as an incident of a larger right of privacy. ${ }^{42}$ As evidence that trade secret law was a manifestation of privacy protection, they observed that courts would not fail to accord protection against the unlawful discovery of trade secret knowledge by eavesdropping ${ }^{43}$ or wrongfully obtained access, which protection was explainable on

36. Warren \& Brandeis 193-94. This development of the law was said to be inevitable and an example of the capacity for growth which characterized the eternal youth of the common law. Id. at 195 .

37. Intellectual property is the law relating to "the protection afforded thoughts, sentiments, and emotions, expressed through the medium of writing or of the arts, so far as it consists in preventing publication ...."Id. at 205.

38. Id. at 213.

39. Id. at 206, 213. See WESTIN 344-46.

40. Proceeding from the first case adopting the right of privacy, Pavesich v. New England Life Ins. Co., 122 Ga. 190, 50 S.E. 68 (1905), the privacy law soon spread to the other states. See F. HARPER \& F. JAMES, THE LAw OF TORTS $\$ 9.6$ (1956) [hereinafter cited as HARPER \& JAMES]; W. Prosser, Torts $\S 112$ (3rd ed. 1964) [hercinafter cited as Prosser]; Westin 346- 47. An exhaustive bibliography is contained in 1 CALLMANN $\$ 3.3$, at 54 n.83.

A classic discussion of privacy protection vis-à-vis eavesdropping is contained in the dissent of Mr. Justice Brandeis in Olmstead v. United States, 277 U.S. 438, 474 (1928).

41. The law of trade secrets is discussed in some detail at notes $70-76$ infra and accompanying text.

42. Warren \& Brandeis 212.

43. Eavesdropping was, at any rate, a crime itself at common law. 4 W. BLACKSTONE, COMMENTARIES ${ }^{*} 169$. By the growing trend of statutory provision, eavesdropping is regaining its criminal stature. See, e.g., GA. CODE ANN. § 26-3001 (Supp. 1970); MICH. Comp. LAws ANN. $\S 750.539$ (d) (1968). See note 150 infra and accompanying text. 
neither contract nor confidence theories. ${ }^{44}$ Warren and Brandeis a]so foresaw that profit-making consequent to the commercial exploitation of intellectual rights was a further area which was afforded relief under the privacy doctrine, ${ }^{45}$ as such protection, also, was unexplainable on other grounds.

\section{Non-Protection for the Corporation}

The application of contract, trust, and confidence doctrines, which had been used to protect individuals in earlier times, also became the principal means of relief to commercial enterprises whose secrets had been unlawfully appropriated by competitors. ${ }^{46}$ Just as these doctrines proved inadequate to protect the individual from technological surveillance they were also unsatisfactory in the commercial setting. ${ }^{47}$ Given this similarity in both the previously applied doctrines of protection and the technological changes which made those doctrines obsolete, as well as the fact that the Warren and Brandeis article initially dealt with trade secrets and profit-making, it might well have been thought that the law of privacy would be naturally applied in the protection of commercial trade secrets from surreptitious thievery. Such a conceptual development, however, would have required the courts to extend the right of privacy to a corporation,,$^{48}$ a step which the courts have been unflinchingly reluctant to take. ${ }^{49}$ The essential

44. Warren \& Brandeis 212.

45. Id. at 204.

46. 2 CallamanN $\$ 61$; Klein 440; Stedman 22-24.

47. See notes 77-106 infra and accompanying text.

48. It takes little perception to conclude that it is corporations for whom the protection of commercial secrets is crucial. In light of other situations in which corporations are extended forms of privacy protection, this fact alone should not, however, have posed a major hurdle. See notes 142-66 infra and accompanying text.

49. See, e.g., Oasis Nite Club, Inc. v. Diebold, Inc., 261 F. Supp. 173, 175-76 (D. Md. 1966); Vassar College v. Loose-Wiles Biscuit Co., 197 F. 982 (W.D. Mo. 1912); Maysville Transit Co. v. Ort, 296 Ky. 524, 177 S.W.2d 369 (1944). See also 1 HARPER \& JAMES $\$ 9.06$; S. Hofstader \& G. Horowitz, The Right of Privacy $\$ 5.1$ (1964) [hereinafter cited as Hofstadter \& Horowitz]; Prosser § 102; Restatement (Second) of Torts § 652J, comment $c$ (Tent. Draft 13, 1967); Annot., 30 A.L.R.3d 203, 212-13 (1970); Annot., 14 A.L.R.2d 750 (1950). But see E.1. duPont deNcmours \& Co. v. Christopher, 43I F.2d 1012 (5th Cir. 1970); Waring v. WDAS Broadcasting Station, 327 Pa. 433, 194 A. 631 (1937) (Maxey, J., concurring).

Although the courts have generally failed to accord explicit privacy protection to corporations, state legislatures have expanded such protection in response to the industrial espionage threat. See Findings of Georgia Invasion of Privacy Study Committee (which accompanied the submission of GA. CODE ANN. \$ 26-3001 et seq. (Supp. 1970)), reprinted in Hearings on S. 928 610-11. See also notes 150-57 infra and accompanying text. The right of privacy in commercial contexts is discussed in I CALLMANN $\S 3.3$. 
reason for this failure to apply privacy principles to the corporate entity is probably to be found in the traditional reluctance of common law judges to depart from established rules and principles. Just as in earlier centuries plaintiffs were denied relief if they had no writ or pursued the wrong cause of action, their contemporary counterparts are often denied relief if there is no direct precedent for their position. ${ }^{50}$ This rigid stare decisis approach, however, ignores the traditional common law principle extending existing rules to new situations as they arise. ${ }^{51}$

Where the corporate privacy question has appeared, however, the courts have not been presented with the problem of industrial espionage, but rather with three other general situations: governmental regulation, use of corporate names, and voluntary disclosure in confidence.

Corporations have often pleaded that government regulation impinges upon their right of privacy. In the leading case of United States v. Morton Salt Co., ${ }^{52}$ Morton Salt had been directed to submit reports of continuing compliance with Federal Trade Commission orders. This directive was challenged on fourth and fifth amendment grounds. In rejecting these defenses the Court utilized sweeping language to preclude absolutely a corporate privacy right, commenting that since corporations are allowed to operate in interstate commerce by government grace they cannot object to being required to comply with government regulations. ${ }^{53}$ The language of the Court simply followed the principle that government favors often carry an obligation to submit to regulation. ${ }^{54}$ Since Morton Salt, limitcd to its facts, held only that a corporation has no right of privacy vis-a-vis governmental regulatory inquiries, ${ }^{55}$ it is not

50. Lack of precedent was a reason for the rejection of the right of privacy itself in one of the most celebrated cases arising after the Warren and Brandeis article. Roberson v. Rochestcr Folding Box Co., 171 N.Y. 538, 64 N.E. 442 (1902). See Kacedan, The Right of Privacy, 12 Boston U.L. Rev. 353, 354 (1932); Comment, Thoughts Concerning the Status of the Right of Privacy in Texas, 23 Baylor L. REv. 117, 130 (1971).

51. Nizer, supra note 31 , at 557.

52. 338 U.S. 632 (1950).

53. Id. at 652 .

54. Id. The corporation is, however, given protection from unlawful demands made in the name of public investigation. Id. See See v. City of Seattle, 387 U.S. 541 (1967); FTC v. American Tobacco Co., 264 U.S. 298 (1924) (a governmental fishing expedition is far contrary to the principles of justice); United States y. Stanack Sales Co., 387 F.2d 849 (3rd Cir. 1968).

55. In Morton Salt the Court cited United States v. White, 322 U.S. 694 (1944), for the proposition that a corporation is not entitled to claim a right of privacy. White, however, dealt 
necessarily authority for the denial of a corporate right of privacy in other contexts. Nevertheless, Morton Salt has been erroneously cited for the broad proposition that corporations are not entitled to a right of privacy. ${ }^{56}$

Commercial use of one corporation's name by another has also raised the corporate privacy issue. The earliest case involving this problem, and the earliest decision refuting a corporate privacy right, was Vassar College v. Loose-Wiles Biscuit Co. ${ }^{57}$ where Vassar claimed a privacy right to prevent the use of its name and seal by a candy manufacturer. The court, however, rejected Vassar's claim, concluding that the right of privacy protected only injuries to feelings and sensibilities, deprivations that a corporation could not claim. ${ }^{58}$ Although Vassar College was subsequently followed in many jurisdictions, ${ }^{59}$ corporations have recently been included in statutes providing a privacy remedy for the commercial use of name and likeness, ${ }^{60}$ indicating that Vassar College may no longer be entirely credible in those jurisdictions. Notwithstanding these statutes, however, an additional remedy is available in "name use" cases, ${ }^{61}$

with the availability of the privilege against self-incrimination to a labor union official in the face of a government order to produce books and records. The Court commented in dicta that "[s]ince the privilege . . . is a purely personal one, it cannot be utilized by . . . a corporation." Id. at 699 . Both Morton Salt and White use overly broad language and should not be interpreted to bar a privacy cause of action as a remedy for industrial espionage.

56. See, e.g., Fleck Bros. Co. v. Sullivan, 385 F.2d 223, 225 n.7 (7th Cir. 1967); Oasis Nite Club, Inc. v. Diebold, Inc., 261 F. Supp. 173, 175 (D. Md. 1966); Association for the Preservation of Freedom of Choice, Inc. v. Emergency Civil Liberties Comm., 37 Misc. 2d 599, 600, 236 N.Y.S.2d 216, 218 (Sup. Ct. 1962); Restatement (SECOND) OF ToRTs § 652J, comment $c$, at 147 (Tent. Draft No. 13, 1967).

57. 197 F. 982 (W.D. Mo. 1912).

58. Id. at 985. Accord, Jaccard v. R.H. Macy \& Co., 176 Misc. 88, 26 N.Y.S.2d 829 (1941), affd 265 App. Div. 15, 37 N.Y.S.2d 570 (1942); Rosenwasser v. Ogoglia, 172 App. Div. 107, IS8 N.Y.S.2d 56 (1916).

59. See, e.g., University of Notre Dame Du Lac v. Twentieth Century-Fox Film Corp., 15 N.Y.2d 940, 259 N.Y.S.2d 832, 207 N.E.2d 508 (1965) (Notre Dame and its president were denied an injunction against use of the school's name, symbol, and football reputation in the film "John Goldfarb, Please Come Home," despite claims that the right of privacy of the university was violated); Shubert v. Columbia Pictures, 189 Misc. 734, 72 N.Y.S.2d 851 (Sup. Ct. 1947); Horowitz, The Right of a Corporate Entity to Protection of Its "Privacy" or Rather of Its Right of Property In Name, Likeness, 16 VA. L. WeEkLy DICTA CoMP. 104 (1965); Annot., 30 A.L.R.3d 203 (1970) (invasion of privacy-name or likeness). The cases following Vassar College have been termed "unnecessarily restricted views." Nizer, supra note 31, at 550.

60. See, e.g., UTAh Code ANN. $§ 76-4-9$ (Supp. 1968). But see Fla. Stat. AnN. $\$ 540.08$ (Supp. 1970); OKLa. Stat. ANN. ch. 2I, § 839 (1958).

61. See, e.g., Cornell Univ. v. Messing Bakeries, 285 App. Div. 490, 138 N.Y.S.2d 280 affd, 309 N.Y. 722, 128 N.E.2d 42 I (1955). See also 1 Nims $\S 83$; Prosser $\S 112$, at 843-44; Horowitz, supra note 59, at 104-05. 
suggesting that denial of a corporate privacy right in those cases should be no basis for its denial in other contexts devoid of a viable alternative remedy.

The final corporate privacy area already substantially litigated-voluntary disclosure in confidence-presents situations more closely analogous to industrial espionage. ${ }^{62}$ The first significant confidence decision was Maysville Transit $v$. Ort ${ }^{63}$ where plaintiff corporation sought recovery upon a right of privacy theory for the publication of its income tax return. The claim was denied on the ground that the right of privacy protects the feelings and sensibilities of individuals, not their property, business, or other pecuniary interests. ${ }^{64}$ Similarly, in Copley v. Northwestern Mutual Life Insurance $C_{0 .}^{65}$ plaintiff partnership had disclosed business statistics to the agent of defendant insurance company, who subsequently disclosed them to the plaintiff's competitors. Recovery was premised upon a breach of confidential relationship and the partnership's right of privacy. The court, however, denied the right of privacy using language similar to that in Maysville Transit. ${ }^{66}$ Both Copley and Maysville Transit, however, involved a wrong for which an existing remedy was available. In Copley the right of privacy claim failed, yet a cause of action had been stated for the improper disclosure of trade secret information obtained in confidence; ${ }^{67}$ and in Maysville Transit a cause of action had been stated for violation of a Kentucky statute concerning the confidentiality of a tax return. ${ }^{68}$ As with the improper use of corporate names, thcrefore, the confidence situation is inappropriate for inclusion within the corporate right of privacy since it is afforded adequate remedy under existing doctrine.

In the above three contexts a corporate privacy right has been

62. The confidential relation doctrine is probably the most frequently invoked trade sccret remedy. The doctrine states that one has a right to maintain the secrecy of his sccrets, that disclosure in confidence does not breach the secrecy, and that breaches of the confidence are actionable. See notes 79-85 infra and accompanying text.

63. 296 Ky. 524, 177 S.W.2d 369 (1944).

64. Id. at 526, 177 S.W.2d at 370.

65. 295 F. Supp. 93 (S.D.W. Va. 1968).

66. Id. at 95. In dispensing with the privacy claims both the Maysville Transit and Copley courts used identical language to conclude that the right was never designed to protect "business or other pecuniary interests." Such statements are simply inaccurate since Warren and Brandeis specifically alluded to the fact that the right could protect future profits which were threatened by the wrongful discovery of secret information. See note 45 supra and accompanying text.

67. 295 F. Supp. at 96.

68. $296 \mathrm{Ky}$. at $526-27,177$ S.W.2d at 371 . 
clearly denied. With regard to government regulation, the denial is probably proper-so long as business is protected against governmental overreach. Likewise, use of corporate name and breach of confidence situations do not demand such a remedy, but for a different reason, since existing remedies are available to redress such grievances, the courts, exercising traditional judicial restraint, simply choose to utilize them. While the corporate right of privacy has thus been rejected where its application was not necessary, such action should not be precedent to deny its existence in an area where it is needed-industrial espionage. ${ }^{69}$

\section{A Right of Privacy for the Corporate Victim of Industrial ESPIONAGE}

\section{The Need for Privacy Protection}

The need for a corporate right of privacy as a remedy for the victims of industrial espionage becomes apparent when existing remedies are considered in relation to the espionage phenomenon. The basic principle underlying the common law doctrines affording protection to commercial secrets is the law of trade secrets. A trade secret is most generally defined as any compilation of information which is used in the business of its owner and which provides a competitive advantage over anyone without its benefit. ${ }^{70}$ The bases of trade secret protection have been variously stated, " but the "essence" of the law is that the trade secret will be protected against unfair and improper conduct. ${ }^{72}$ One is not prevented from lawfully discovering-whether by copying or reverse engineering-the trade

69. It could be argued that a corporate right of privacy was recognized in Friedman $v$. Restaurant Employees, 20 Ohio Op. 473 (C.P.), rev'd on other grounds 86 Ohio App. 189, 90 N.E.2d 447 (1941). Plaintiff sought to enjoin the picketing of his restaurant; the court observed that "[w]hile it is true that this right of privacy . . . is one to be asserted by the individual, yet when sucb right is interferred with for the deliberate purpose of affecting the business of a third person ... then such act becomes a tortious one and should be protected." Id. at 477 . A corporate rigbt of privaey was recognized in E.I. duPont deNemours \& Co. v. Christopher, 431 F.2d 1012 (5th Cir. 1970), discussed at length at notes 96-104, 158-66 infra, and in Waring v. WDAS Broadcasting Station, 327 Pa. 433, 442, 194 A. 631, 635 (1937) (Maxey, J., concurring).

70. ReSTATEMENT OF TORTS $\S 757$, comment $b$ (1939). "It may be a formula for a chemical compound, a process of manufacturing, treating or preserving materials, a pattern for a machine or other device, or a list of customers." Id.

71. 2 Callmann $§ 51$; Milgrim § 1.01; Stedman 17-24.

72. 2 CallmanN $\S 51$. Trade secret law is essentially concerned witb the circumstances in which the trade secret owner will receive protection against the commercial use of the secret by others. Developments-Competitive Torts 948. 
secrets of his competitors, ${ }^{73}$ but one is prohibited from discovering another's secrets by theft, bribery, stealth, breach of confidence, or other improper or unlawful means. ${ }^{74}$ This protection enables the trade secret owner to deprive the public of the benefits of his discovery by concealing and commercially exploiting the secret to his own advantage. ${ }^{75}$ The right is extinguished, however, and its protected status lost, when the public learns of the discovery by fair and lawful means. Once the secret is in the "public domain," either by publication or lawful discovery, it is available for general use and application. ${ }^{76}$

Since it is the improper means of discovery against which the law is directed, and not the trade secret rights themselves, ${ }^{77}$ common law doctrines of unfair competition judicially evolved as a function of the means employed. Broadly, these doctrines provide that where a contractual or confidential relationship exists between the owner and improper discoverer, the owner may predicate recovery upon either contract or breach of confidence grounds. Where such relationship is not present, the owner may pursue a misappropriation action. ${ }^{78}$

Inasmuch as the most common source of trade secret litigation is

73. 2 CallmanN $\S 53.3(\mathrm{a}) ; 1$ Nims $\S 148$.

74. The discovery rules have been described as follows: "One may use his competitors process if he discovers the process by reverse engineering applied to the finished product . . . [or] by his own independent research; but one may not avoid thesc labors by taking the process from the discoverer without his permission at a time when he is taking reasonable precautions to maintain its secrecy." E.l. duPont deNemours \& Co. v. Christopher, 431 F.2d 1012, 1015 (5th Cir. 1970).

75. Developments-Competitive Torts 948.

76. The fundamental basis for legal protection, as the trade secret name suggests, is that the data in question be retained in secrecy. RESTATEMENT OF TORTS $\S 757$, comment $b$ (1939); Stedman 6. See also 2 CallmanN $\S 53.3$; Milgrim $\$ \S 2.05,2.06$; 1 Nims $\S 142$. For discussion of particular aspects of the trade secret law, see 2 CALLMANN $\S \S 51-59 ; R$. ELLis, Trade Secrets (1953) [hereinafter cited as Ellis]; Milgrim; 1 Nims ch. 11; A. TURner, The LAW of Trade Secrets (1962). A concise survey may be found in Klein 437-44; Developments-Competitive Torts 948-50.

77. It is only in an exceptional case that trade secret rights are themselves the basis of an action. Rather, in the normal situation, attention is directed toward the improper means by which the trade secret was discovered-by unfairness, breach of confidence, or other tortious interference. 2 CALLMANN $\S 53.2(\mathrm{~b})$.

78. Id. $\S 51$. Misappropriation is a branch of the unfair competition doctrine which is generally said to have been initiated by Justice Pitney in International News Serv. v. Associated Press, 248 U.S. 215 (1918). The theory of misappropriation deals with the copying, as opposed to the taking, of otherwise protected intangible property which is, of necessity, in the public domain. The doctrine is discussed in detail in Developments-Competitive Torts 932-47. Obviously, the theory of misappropriation would afford little protection to the industrial espionage victim, whose stolen intangibles had bcen held in secrecy. 
the employee who departs with his former employer's trade secrets, ${ }^{79}$ the breach of confidence doctrine is probably the most frequently invoked remedy. ${ }^{80}$ The basic premise of that doctrine is that the owner of a commercial secret has the right to maintain the secrecy against strangers to the confidence. ${ }^{81}$ To recover, the deprived owner must prove the existence of a trade secret disclosed to his employee under an obligation of secrecy and confidence ${ }^{82}$ and that such obligation was

79. Doerfer, The Limits on Trade Secret Law Imposed by Federal Patent and Antitrust Supremacy, 80 HARv. L. Rev. 1432; 1435 (1967); Klein 453; Industrial Secrets 328; Note, 54 lowA L. Rev., supra note 6, at 1166 . Ironically, employee loyalty is believed to be one of the best defenses against this sort of industrial espionage. Furasch, Industrial Espionage, HaRv. Bus. Rev., Nov.-Dec. 1959, at 6, 164.

This is discussed as "run of the mill" litigation. Klein 462. The common faet situation will involve an employee possessing information crucial to his employer's competitive advantage. The employee will leave, join a competitor, and the competitive advantage will subsequently be manifested in the competitor's product. See, e.g., Carter Prods., Inc. v. Colgage-Palmolive Co., 130 F. Supp. 557 (D. Md. 1955), aff d 230 F.2d 855 (4th Cir. 1956) (here the employee sought out the competitor with instant shaving creme secrets which the competitor had been unable to develop, and which had given the former employer a monopolistic position); Schulenberg v. Signatrol, Inc., 33 III. 2d 379, 212 N.E.2d 865 (1965) (subsequent competitor's activity based upon former employer's drawings); National Rejectors, Inc. v. Trieman, 409 S.W.2d 1 (Mo. 1966) (employees established competing slug-rejector manufaeturing eompany); Minnesota Mining \& Mrg. Co. v. Technical Tape Corp., 23 Misc. 2d 671, 192 N.Y.S.2d 102 (Sup. Ct. 1959); B.F. Goodrieh \& Co. v. Wohlgemuth, 117 Ohio App. 493, 192 N.E.2d 99 (1963) (an employee departed with particular knowledge of space suit design which had made the former employer the undisputed market leader). The departing employee in the computer software industry is discussed in Bender 913.

Although a departing employee is not strictly speaking a surreptitious device, employees may be used as devices of industrial espionage. A competitor might place his own employees in his competitor's plant and thus obtain competitive secrets. This, in fact, was the means by which German steel czar Alfred Krupp obtained the seerets of the British forgemasters. See generally Klein 462. The use of such undercover agents is effective, difficult to detect, and may continue for an indefinite period. Smith, supra note 1, at 121. Relief is, however, available. In Eastern Extracting Co. v. Greater New York Extracting Co., 126 App. Div. 928, 110 N.Y.S. 738 (Sup. Ct. 1908), a spy was placed in a competitor's plant and the court allowed the competitor relief, noting that "a man cannot, through deceit and by means of an appeal for employment as a laborer . . ., enter the household of his benefactor and steal his belongings." Id. at 931, 110 N.Y.S. at 741 .

80. Industrial Secrets 329. The confidenee doctrine may also appear where disclosure is made to a prospective purchaser, licensee, lender, or to an agent, partner or joint venturer. See 2 Callman $\S 51.2$; Milǵrim $\S \S 5.01-.05$; Restatement of TorTs $\S 757$, comment $j$ at 13 (1939); Doerfer, supra note 79, at 1435-39.

81. Board of Trade v. Christie Grain and Stock Co., 198 U.S. 236 (1905); Peabody v. Norfolk, 98 Mass. 452 (1868); Elus $\S 1$.

82. The confidential relation may be either express or implied. Heyman v. A.R. Winarick, Inc., 325 F.2d 584, 586-87 (2d Cir. 1963); 2 CallmanN $\$$ 51.2(d). If there is no contractual commitment, the disclosure must be specific or in concrete form. Bimba Mfg. Co. v. Starz, 119 III. App. 2d 185, 256 N.E.2d 357 (1969). But in National Rejectors, Inc. v. Trieman, 409 S.W:2d 
subsequently breached to his probable detriment. ${ }^{83}$ Although the confidence doctrine has proven to be a viable remedy, ${ }^{84}$ the typical industrial espionage situation involves no confidential relationship. Thus, in cataloguing the scope of protection offered by existing remedies, it has been observed that electronic surveillance will cause the trade secret doctrine to decline as a protector of commercial secrets because the trade secret pirate is no longer dependent upon the cooperation of disloyal confidants. ${ }^{85}$

1 (Mo. 1966), the court indicated that such a relation could not be found from the mere fact of the employment relation. $I d$. at 35 . An interesting debate has developed as to the validity of employee contractual promises of non-disclosure of his employer's trade secrets. The parameters of the problem are outlined and developed in 2 CaLLMANN $\S 51.2$ (c); MILGRIM $\$$ 2.01-.09.

83. Macbeth-Evans Glass Co. v. Schnelbach, 234 Pa. 76, 87, 86 A. 688, 691 (1913). The wrongdoing is the breach of the confidence, not a misappropriation of property. Servo Corp. of America v. General Elec. Co., 393 F.2d 551, 555 (4th Cir. 1968). In E.I. duPont deNemours Powder Co. v. Masland, 244 U.S. 100, 102 (1917), Justice Holmes said that "[t]he property may be denied but the confidence cannot be."

84. Although the remedy was effective in the past, it could be argued that it has been sapped of much of its strength. The departing employee situation typifies this trend of judicial decision in the confidence area. The crux of the issue there is that the interests of the former employer and the departing employee are necessarily at odds once the employment relationship is severed. The employer naturally desires to inhibit the dissemination of his trade secrets, while the employee desires to be unhampered in the use of his acquired skills, knowledge, and experience and to be free from employment mobility restraint. Wexler v. Greenberg, $399 \mathrm{~Pa} .569,578-79,160$ A.2d 430, 434-35 (1960); 2 CALLMANN $\S 54.2$. To protect both interests, the courts must weigh not only the relative business interests of the employer and the employee, but also possible deleterious effects upon both innovation and the freedom of movement of employecs. Id. \$ 54.2(a); 54 Iowa L. Rev., supra note 6, at 1185 . These competing demands have been resolved by the judicial adoption of a theory allowing the departing employee to draw upon his general skill and knowledge in subsequent employment as long as he does not impinge upon specific trade secrets of his former employer. I Nims $\S$ I49; A. TURNER, TRADE SECrETS $\S \S 161-63$ (1962). This oversimplified principle is, of course, much easier to state than to apply.

Recent decisions reveal that courts are giving controlling weight to employee mobility by setting increasingly strict requirements for employer recovery. See Sarkes Tarzian, Inc. v. Audio Devices, Inc., 166 F. Supp. 250 (S.D. Cal. 1958), affd mem., 283 F.2d 695 (9th Cir. 1960), cert. denied, 365 U.S. 860 (1961); Wexler v. Greenberg, supra; Industrial Secrets 336; Developments-Competitive Torts 950-53. To establish the threshold requirement of a trade secret, an employer may be required to meet a standard of proof and discovery which exceeds that in any other trade secret context and which has been described as essentially synonymous to a patent standard. Kalinowski, Key Employees and Trade Secrets, 47 VA. L. REv. 583, 590 (1961); Industrial Secrets 340. But see Water Servs., Inc. v. Tesco Chems., Inc., 410 F.2d 163, 172-73 (5th Cir. 1969); MiLGRIM $\S 2.08[3]$.

This restricted interpretation of the confidence remedy as applied to the departing employee could be seen as a bellweather leading to similar consequences in other areas of commercial secret protection. In fact, this would appear to be the direction being taken by the Supreme Court. See the discussion of Lear, Inc. v. Adkins, 395 U.S. 653 (1968); Sears, Roebuck \& Co. v. Stiffel Co., 376 U.S. 225 (1964); and Compco Corp. v. Day-Brite Lighting, Inc., 376 U.S. 234 (1964), at notes 167-202 infra and accompanying text.

85. Industrial Espionage 918-19. This article contains a catalogue of the various remedies 
Without reliance upon trade secret doctrines, one might seek to invoke other traditional legal remedies for the surreptitious taking of commercial secrets. An action might be brought upon either a trespass or theft theory. But the trespass action would require the showing of an entry, ${ }^{86}$ not often present when electronic devices are used, and consequently would probably not succeed against the industrial espionage pirate. ${ }^{87}$ The theft theory is more plausible, but has been equally unsuccessful. To obtain relief under stolen property statutes one must generally have been deprived of tangible property and that label excludes intangibles such as trade secrets and other commercial information. ${ }^{88}$ Therefore, the stolen property acts offer little solace to the industrial espionage victim. ${ }^{89}$

As one means of combatting this lack of protection, it might be argued that since the emergence of industrial espionage is yet another manifestation of the traditional problem of unfair competition, the doctrines which developed there against should apply notwithstanding the distinctions noted. But this is simply not the case. The doctrines related to unfair competition are concerned with activity the results of which are cognizable wrongs-for example, a breach of confidence, misrepresentation, misappropriation, or actual theft. Industrial espionage, on the other hand, results from activity whose consequences may not only be uncognizable, but may also be difficult, if not impossible, to prove in a court of law.90 Industrial

which might be applied in the industrial espionage context. Id. at 915-25. See also 1 CALLMANN $\S \S 4-8$. The doctrine of misappropriation would also be of little value in the context of industrial espionage. See note 78 supra.

86. 1 Harper \& James $\S 1.5$; Prosser $\S 13$.

87. Industrial Espionage 919 n.46.

88. See Hawkland, Some Recent American Developments in the Protection of Know-How, 20 Buffalo L. REv. 119, 123-24 (1970); Industrial Espionage 915-18. For example, the National Stolen Property Act, 18 U.S.C. $\S 2314$ (1964), punishes the asportation of "goods," a term which has been traditionally considered to include only tangible property capable of being physically carried in interstate commerce. Although the definition of "goods" was expanded in United States v. Lester, 282 F.2d 750 (3d Cir. 1960), cert. denied, 364 U.S. 937 (1961), and United States v. Seagraves, 265 F.2d 876 (3d Cir. 1959), to include the informational content of maps, and in United States v. Bottone, 365 F.2d 389 (2d Cir.), cert. denied, 385 U.S. 974 (1966), to include copies of documents, the Act is still considered inapplicable to intangibles.

Several states have adopted statutes which do cover the theft of trade secrets. See note 106 infra. Amendments have also been offered unsuccessfully to the National Stolen Property Act. See Hawkland, supra, at 123-24.

89. Hawkland, supra note 88, at 123 n.17; Industrial Espionage 915-18. In United States v. Bottone, 365 F.2d 389, 393 (2d Cir. 1966), the court indicated that the National Stolen Property Act would not apply to electronic espionage.

90. The problem of proof is probably the most difficult obstacle facing the industrial 
espionage is not, therefore, simply another form of unfair competition.

In view of the uncertain applicability of these existing doctrines to the practice of commercial surveillance, industrial espionage would appear to be a "good gamble."91 The potential industrial espionage pirate knows that electronic surveillance is likely to allow him to steal secrets with the victim either not realizing the loss, being unable to prove the necessary elements of recovery, or fearing complete publication of his secret. ${ }^{92}$ Even were he to believe that his particular acts would create the opportunity to apply an existing remedy, the potential pirate could be confident that the resulting injunction ${ }^{93}$ or damage award ${ }^{94}$ would be unlikely to leave him any worse off than he was before he undertook his piracy.$^{95}$

espionage victim, since secret information may be acquired through the use of eavesdropping equipment preventing him from realizing the loss. To prove that the information was used to the detriment of the victim is also difficult, since what is stolen is often little more than competitive strategy. If the stolen item is a research secret, it is likely that it has not yet been manifested in salable form, making damage calculation diffieult. See generally Industrial Espionage 925.

91. Developments-Competitive Torts 954.

92. Id.

93. The older rule was that trade secret violations would be subjected to permanent injunction. Shellmar Prods. Co. v. Allen-Qualley Co., 87 F.2d 104 (7th Cir. 1936), cert. denied. 301 U.S. 695 (1937), refusing to modify, 36 F.2d 623 (7th Cir. 1929); A.O. Smith Corp. v. Petroleum Iron Works Co., 74 F.2d 934 (6th Cir. 1935), modifying 73 F.2d 53 (6th Cir. 1934). Such a result, of course, puts the owner in a better position than he would have been without the discovery. Developments-Competitive Torts 958-59. Following Conmar Prods. Corp. v. Universal Slide Fastener Co., 172 F.2d 150 (2d Cir. 1949), however, the general trend today is to allow only a temporary injunction. Winston Researeh Corp. v. Minnesota Mining \& Mfg. Co., 350 F.2d 134 (9th Cir. 1965); Sehreyer v. Casco Prods. Corp., 190 F.2d 921 (2d Cir. 1951), cert. denied. 342 U.S. 913 (1952). The use of temporary injunctions is in accordance with the rules which the Supreme Court has promulgated in its "right to copy" cases, which are discussed in detail at notes 167-74 infra. See Hampton v. Blair Mfg. Co., 374 F.2d 969 (8th Cir. 1967).

94. If the victim can prove no lost profits, he can reeover only nominal damages, and if the pirate is financially insecure, he is essentially judgment proof. In short, the threat of an accounting for profits is likely to have little deterrent effect on the potential pirate. Industrial Espionage 927-28. Furthermore, a damage recovery is unlikely to recompense the loss of a truly valuable secret. See Harding, Trade Secrets and the Mobile Employee. 22 Bus. LAw. 395, 400 (1967).

95. Developments-Competitive Torts 954 . This view may be illustrated by Schulenberg v. Signatrol, Inc., 33 111: 2d 379, 212 N.E.2d 805 (1965), where unfair competition was found when a former employee covertly took blueprints and employed them to establish a competing business. The remedy accorded was an injunction limited to the period of time reasonably required for an ex-employee to produce copies legally. Similarly, in National Rejectors, Inc, v. Trieman, 409 S.W.2d I (Mo. 1966), although the court found that former employees had utilized their prior employer's drawings improperly, it disallowed injunctive relief and limited damage recovery to those profits lost during the period in which the competitor, but for plaintiff's improperly used drawings, would not have been in production. The recoveries in both 
That such a belief by a potential pirate is well founded is made apparent by the factual background of a presently pending lower federal court case. This case is also to be seen as perhaps the most compelling evidence of the need for a corporate right of privacy because it exemplifies the current issue of whether existing remedies afford recovery against the industrial espionage agent. $\ln$ E.I. duPont deNemours \& Co. v. Christopher ${ }^{96}$ duPont had possessed a highly secret, but as yet unpatented, competitively advantageous process for the making of methanol. Although special secrecy precautions had been taken during the lengthy and expensive development period, for a brief time during the construction of the production plant, the new process was visible from the super-adjacent airspace because of an unfinished roof. ${ }^{97}$ During this period an airplane, piloted by the independent contractor of a competitor, flew over the plant, and photographs were taken of the visible process. The pictures were conveyed to the competitor, who would be able to reduce them to drawings of his own. Upon learning of the piracy, duPont management brought suit alleging wrongful discovery of a trade secret and asked for damages and temporary and permanent injunctions. Arguing the inapplicability of the available forms of relief, the defendant contended that its activity fit none of the existing trade secret or unfair competition doctrines and was not, therefore, unlawful. ${ }^{\text {s }}$

To characterize the aerial photography in Christopher as being within the stolen property doctrines would require an unrealistic expansion of the most liberal ${ }^{a}$ decisions construing the concept of what is subject to theft. ${ }^{99}$ There was also no breach of confidence, ${ }^{100}$ no

Schulenberg and National Rejectors are insufficient to make the victimized employer whole and are unlikely to deter those bent on unfair practices. See Klein 464-65; Industrial Secrets 336; notes 105-06 infra and accompanying text. The implicit reasoning behind this type of relief is the same as that given for the change in direction of the departing employce cases - a preference for information dissemination and employee mobility. See note 84 supra.

96. 431 F.2d 1012 (5th Cir. 1970), cert. denied, 400 U.S. 1024 (1971), noted 2 ST. MarY's L.J. 247 (1970). It must be borne in mind when evaluating the Christopher case that it came before the Fifth Circuit on interlocutory appeal under 28 U.S.C. $\S 1292$ (b) (1964) from the district court's finding that du Pont had stated a claim upon which relief could be granted.

97. The court did not indicate why the roof was unfinished at this critical stage of construction.

98. $431 \mathrm{~F} .2 \mathrm{~d}$ at 1014 . See note 105 infra and accompanying text.

99. See notes 88-89 supra and accompanying text. As noted previously, United States v. Bottone, 365 F.2d 389 (2d Cir. 1966), broadly indicated that the National Stolen Property Act would not apply to industrial espionage activity.

100. A breach of confidence cannot exist where there is no relation of confidence upon which 
misappropriation, ${ }^{101}$ and probably none of the other wrongs contemplated in the rubric of unfair competition. ${ }^{102}$ Although a trespass action could be brought, ${ }^{103}$ it would not likely compensate the plaintiff for the acquisition of its secret. ${ }^{104}$ Thus, the court could grant relief to the plaintiff, absent the availability of a corporate right of privacy, only by considerable perversion of the scope 'of existing doctrines.

As a consequence of these several factors, those surveying the usefulness of traditional trade secret remedies for the industrial espionage victim have concluded that they are, for that purpose, essentially useless. ${ }^{105}$ Recognizing the need for an adequate remedy, these same observers have proposed a panopoly of new theories to aid the industrial espionage victim. ${ }^{106}$

to erect a duty. Warren \& Brandeis 212; Induștrial Espionage 919. See notes 84-85 supra and accompanying text.

101. That doctrine relates generally to the provision of legal security for intangibles which are of necessity open to public disclosure. See note 78 supra.

102. See generally Developments-Competitive Torts 947-59; Industrial Espionage 918-21.

103. Swetland v. Curtiss Airports Corp., 41 F.2d 929 (N.D. Ohio 1930); Smith v. New England Aircraft Co., 270 Mass. 511,170 N.E. 385 (1930); 1 HARPER \& JAMES $\$ 1.5$.

104. The availability of a trespass action must be considered in light of the navigable airspace claimed by the United States. 49 U.S.C. $\$ 1301(24)$ (1964); United States v. Causby, 328 U.S. 256 (1946). Thus, flight in the airspace above 1,000 feet in congested, and 500 feet in uncongested, areas is not subject to a trespass action by the owners of the ground below. 14 C.F.R. $\$ 91.79$ (1970). 1 HARPER \& JAMES $\S 1.5$. Even where a trespass action is available, the recovery is likely to be nominal. See, e.g., Smith v. New England Aircraft Co., 270 Mass. 511 , 532,170 N.E. 385,394 (1930).

105. This has been the predominant conclusion of those who have corrclated existing remedies with industrial espionage activity. The "current legal framework is now inadequate to defend the American equilibrium on privacy from new surveillance techniques." WESTIN 369. "Civil remedies in this country appear helpless in halting disloyal and unfair practices . . . ." Klein 462, 463-64. See Stedman 32; Developments-Competitive Torts 954; Industrial Espionage 927; Industrial Secrets 326-30. But see Harding, supra note 94, at 400-01.

106. Four types of remedies have been emphasized:

(1) Stiffer criminal penalties. MILGR1M \$ 5.05; Bartenstein, supra note 10, at 822; Klein 45965; Developments-Competitive Torts 955 (suggesting the possibility of treble damages in trade secret cases, as is the case in patent law). Several states have enacted legislation making the theft of trade secrets subject to criminal sanction. See GA. Code ANN. $\$ 26-1809$ (Supp. 1970); lLl. ANN. Stat. ch. 38, § 14-1 et seq (Smith-Hurd 1964); IND. ANN. STat. § 10-3048 et seq. (Supp. 1970); Neb. Rev. Stat. § 28-548.01 et seq. (Supp. 1969); N.J. Stat. ANN. § 2A:119. 5.1 et seq. (1969); N.Y. PEnal Law $\$ \S 155.00,155.30$ (McKinney 1967); Wisc. STAT. ANN. $\S 943.205$ (Supp. 1970). See also A BA Section of Patent, TradeMark \& Copyright Law Proceedings 95-97 (1970); 45 Neb. L. ReV., supra note 9, at 648-50.

(2) Proscription of surveillance per se. Industrial Espionage 929. See GA. CoDE ANN. $\$ 26-$ 3001 (Supp. 1970); Mich. Comp. LAws ANN. $\$ 750.539$ (d) (1968). See note 150 infra and accompanying text. See also S. 928, 90th Cong., Ist Sess. (1967) (Right of Privacy Act of 1967).

(3) A limited grant of statutory protection comparable to the German Gebrauchsmuster 


\section{The Denial of Privacy Protection}

In light of the inapplicability of the traditional means utilized to afford protection for commercial secrets, the need for a corporate right of privacy as an industrial espionage remedy is clear. As has been observed, however, the application of privacy principles to the corporation has been a step that both courts ${ }^{107}$ and commentators ${ }^{108}$ have been unwilling to take. As a foundation for the argument that such a right should now be recognized, it is necessary first to survey the reasons for this total denial and to determine their viability.

Privacy is a Personal Right Only. The first reason given for refusal has been that the right of privacy is a right intended only to protect the private sensibilities of natural persons, and not for the protection of business or other pecuniary interests. ${ }^{109}$ This assertion is not only in conflict with the original thought of Warren and Brandeis, ${ }^{110}$ but has been rejected as a basis for not according other privacy-related privileges to corporations. In the law of evidence, for example, corporations are provided broad protection against divulgence of both their trade secrets and their secret communications during litigation. ${ }^{111}$ Most pertinent, for present purposes, amongst the evidentiary privileges is the attorney-client privilege. ${ }^{112}$ Although this

(requiring a given minimum level of novelty and originality), which would provide in essence an extension of the patent laws. Stedman 32.

(4) A right of privacy. Horowitz, supra note 59, at 108 (suggesting that the courts will soon add another chapter to the law by adopting a corporate and associational right of privacy). See Industrial Espionage 925-34 for a summary of all the proposals thus far advanced.

107. Vassar College v. Loose-Wiles Biseuit Co., I97 F. 982 (W.D. Mo. 1912); Maysville Transit Co. v. Ort, 296 Ky. 524, 177 S.W.2d 369 (I944). Sce note 49 supra and accompanying text.

108. I Harper \& James $\S 9.6$; Hofstadter \& Horowitz $\$ 5.1$; Prosser $§ 112$.

109. Copley v. Northwestern Mutual Life Ins. Co., 295 F. Supp. 93 (S.D.W. Va. 1968); Maysville Transit Co. v. Ort, 296 Ky. 524, 177 S.W.2d 369 (1944); Restatement (SeCOND) OF ToRTs $\S 652$ J (Tent. Draft 13, 1967).

110. See note 45 supra and accompanying text.

111. 2 CallmanN $\S 53.3(\mathrm{c})$; Ellis $\S \S 265-80$; Milgrim $\S 7.06 ; 1$ Nims $\S 147 ; 8 \mathrm{~J}$. Wigmore, Evidence $\S 2212$ (McNaughton ed. 196I); Note, Protection and Use of Trade Secrets, 64 HARV. L. REv. 976, 983-84 (195I).

112. There is perhaps, no principle of law which rests on a sounder basis, or which is supported by a more uniform chain of adjudication, than that which holds all information acquired by an attorney from his client . . . as privileged communications. Parish v. Gates, 29 Ala. 254, 259 (1856).

See Simon, The Attorney-Client Privilege as Applied to Corporations, 65 YALE L.J. 953 (1956); Comment, The Lawyer-Client Privilege: Its Application to Corporations, The Role of Ethics, and Its Possible Curtailment, 56 Nw. U.L. Rev. 235 (1961); Note, Attorney-Client Privilege for Corporate Clients: The Control Group Test, 84 HARv. L. REv. 424 (1970). 
privilege had long been assumed to apply to corporate as well as "natural" clients, ${ }^{113}$ a federal district court decision in $1962^{114}$ challenged that belief and precipitated a discussion by the Seventh Circuit in Radiant Burners, Inc. v. American Gas Association..$^{115}$ The district court had held that, since the attorney-client privilege was historically created only for natural persons, it could not be invoked by a corporation. ${ }^{116}$ The Seventh Circuit reversed, concluding that the privilege belongs to the client regardless of his corporate or noncorporate character. ${ }^{117}$ Thus, by invoking the attorney-client privilege a corporation seeking legal advice from an attorney may prevent disclosure of confidential information relating to the advice sought. ${ }^{118}$ This privilege, then, affords the corporation a range of protection which has been described as an instance of a right of privacy. ${ }^{119}$

Similarly, in response to the assertion that a defamation action might be pursued only by a private individual, it has been argued that a corporation should not be denied a cause of action for defamation on the ground that it has no "personality"-that is, feelings and sensibilities-since the corporation, in effect, does have a personality embodied in its business reputation protected by law. ${ }^{120}$ Thus, the corporation may seek to rectify aspersions cast upon its management and credit. ${ }^{121}$ Additionally, corporations are included in statutes

113. See Annot., 98 A.L.R.2d 241, 242 (1964).

114. Radiant Burners, Inc. v. American Gas Ass'n, 207 F. Supp. 771 (N.D. Ill. 1962), rev'd, 320 F.2d 314 (7th Cir. 1963).

115. 320 F.2d 314 (7th Cir. 1963).

116. 207 F. Supp. at 773.

117. $320 \mathrm{~F} .2 \mathrm{~d}$ at 322 . This is consistent with the view that where corporations are placed in identical circumstances with individuals, they will be given the same protection. Maysville Transit v. Ort, 296 Ky. 524, 526, 177 S.W.2d 369, 371 (1943).

118. Even if the attorney-client privilege is for some reason not available, the corporation may yet be protected under the "work-product" doctrine of Hickman v. Taylor, 329 U.S. 495 (1947). The attorney's work-product protection is separate and distinct from the attorney-client privilege. Natta v. Zletz, 418 F.2d 633 (7th Cir. 1969); In re Nata, 410 F.2d 187 (3d Cir.), cert. denied, 396 U.S. 836 (1969).

119. WESTIN 335.

120. Pullman Standard Car Mfg. Co. v. Steelworkers, 152 F.2d 493, 496 (7th Cir. 1945); 1 HARPER \& JAMES $\S 5.3$.

121. Where any of these factors are proven, a corporation has an action for libel without allegation or proof of special damages. Maytag Co. v. Meadows Mfg. Co., 45 F.2d 299, 302 (7th Cir. 1930); 10 W. Fletcher, Cyc. Corporations $\$ 4887$ (perm. ed. 1970); Prosser $\$ 106$. See also Note, Libel and the Corporate Plaintiff. 69 Colum. L. Rev. 1496 (1969). For a discussion of libel and privacy as they relate to a corporation, see Fleck Bros. Co. v. Sullivan, 385 F.2d 223 (7th Cir. 1967). 
which afford relief for commercial appropriation of name or symbol, ${ }^{122}$ which Prosser defines as an area of privacy protection. ${ }^{123}$

The denial of a corporate right of privacy on the ground that privacy is a purely personal right seems, in view of the judicial rejection of that rationale in other analogous contexts, tenuous at best. ${ }^{124}$

Adequacy of Existing Protection. The second reason for refusing to accept a corporate right of privacy is the assertion that existing doctrine already provides the corporation adequate protection against unfair trade practices. ${ }^{125}$ This point requires no further amplification in light of the preceding discussion ${ }^{126}$ wherein it was observed that existing doctrines are inapplicable to industrial espionage and provide the victim inadequate protection.

Thus, both reasons typically offered for rejection of a corporate right of privacy appear to be little more than inflexible responses to a new use of an old remedy, and are thus not persuasive and ignore the realities of the situation facing the industrial espionage victim.

\section{The Advantages of a Corporate Right of Privacy}

The essential question to be confronted in the advocacy of a corporate right of privacy is: what presently unavailable benefit will it confer upon either the owners of commercial secrets or upon society in general?

To the owner of commercial secrets-the victim of industrial espionage - the corporate right of privacy would provide several identifiable benefits supporting his primary interest in the maintenance of the secrecy of his information. In light of the inapplicability of the existing remedies for secret asportation, ${ }^{127}$ one

122. See, e.g., UTAH Code ANN. § 79-4-9 (Supp. 1968).

123. Prosser § 112.

124. It may be interjected, however, that this very foundation is the basis for upholding denials to corporations of other privileges which are also aspects of a larger right of privacy. See discussion of United States $v$. White at note 55 supra. In response, it is to be noted that the right of privacy here advocated is not absolute, but like the attorney-client privilege and the protection of the corporate reputation, is directed at only one facet of corporate existence-protection against industrial cspionage.

125. Harris, A Right of Privacy for Incorporated and Unincorporated Associations?. 16 VA. L. WeEKLY DICTA COMP. 97 (1965). This is one of the few articles concerning the application of a right of privacy to a corporation. Harris determines that no such right is necessary, a conclusion this writer believes inaccurate.

126. See notes 77-106 supra and accompanying text.

127. Id. 
advantage of the corporate privacy right would be that the industrial espionage victim would have a means of rectifying the harm suffered because of industrial surveillance.

Another potential benefit of the corporate privacy cause of action is that it would simplify the present complications surrounding the proof required to establish a violation of existing law. In order to prove a violation of traditional trade secret law the victim must prove both the elements of, and the damages consequent upon, a particular wrong. ${ }^{128}$ The acts for which these traditional remedies were designed, however, involve wrongs whose commission and consequent damage are not unduly difficult to establish. Industrial espionage, on the other hand, often involves surreptitious acts whose effects are essentially impossible to prove even if their commission is detected. ${ }^{129}$ To avoid these harsh burdens of proof, a corporate right of privacy would require only that the victim prove the act of espionage. ${ }^{130}$ The law of privacy is an extension of the action of trespass, ${ }^{131}$ rather than an action on the case, and the tort law long ago crystallized the rule that in a trespass action there is no necessity of proof of actual harm. ${ }^{132} \mathrm{lt}$ was the intentional invasion of plaintiff's right itself which was regarded as the tort, not the damages actually inflicted. Thus, invasion of the right of privacy entitles the plaintiff to compensatory damages for the harm naturally suffered upon the invasion, with no requirement of proof of special damages. ${ }^{133}$ Once the plaintiff establishes the cause of action, he may also recover for any special damages which he can prove to have been caused by the breach of privacy. ${ }^{134}$ Where the invasion of privacy could be shown to have been

128. MILGRIM $\S 7.07[1]$. See note 83 supra and accompanying text.

129. The "proof problem" is discussed in Industrial Espionage 927.

130. Id. at 926.

131. HOFSTADER \& HoROwitz $\S 22.1$.

132. Prosser $\S 7$.

133. Pavesich v. New England Life Ins. Co., 122 Ga. 190, 50 S.E. 68 (1905); HOFSTADER \& HOROWITZ § 24.1; Prosser § 112. The fact that damages may not be measured by a pecuniary standard does not bar recovery. Brents v. Morgan, 221 Ky. 765, 299 S.W. 967 (1927). This rule has been applied in situations dealing with eavesdropping and wiretapping. In Roach v. Harper. 143. W. Va. 869, 105 S.E.2d 564 (1956), the court held that a tenant had stated a cause of action for invasion of privacy against her landlord who had placed a "bug" in her apartment, although she alleged neither special damages nor publication. Accord, Hamberger v. East man, 106 N.H. 107, 206 A.2d 239 (1964); Rhodes v. Graham, 238 Ky. 225, 37 S.W.2d 46 (1931) (telephone tap); Annot., 11 A.L.R.3d 1296 (1967). See Restatement (SeCOND) of TorTs § 652I (Tent. Draft No. 13, 1967).

134. Restatement (SeCond) of Torts $\S 652$ I (Tent. Draft No. 13, 1967) provides: 
knowing, the victim could also recover exemplary or punitive damages. ${ }^{135}$

A further advantage to the victim of industrial espionage would be that the corporate privacy right would allow recovery for the theft of any information, not simply that which could meet the definition of a trade secret under the trade secret doctrine, since the privacy invasion itself, not its results, would be punished. It was earlier observed that industrial espionage involves the quest for both technical research trade secret information as well as operational intelligence. ${ }^{136}$ Thus, the application of a corporate right of privacy to an industrial espionage invasion would allow recovery for any breach of security, regardless of whether it encompassed technical or non-technical data. Liability would be placed upon one intentionally making the unauthorized survey, independent of its consequence. The operative element would be the act of surveillance, rather than the piracy of a particular secret. ${ }^{37}$

The social benefit derived from the recognition of a corporate right of privacy for the victims of industrial espionage lies chiefly in the facilitation and implementation of the public goals of promoting competition and innovation and prohibiting wrongful market conduct. It was with those purposes in mind that the courts of a prior age afforded remedies to the victims of unfair trade practices. ${ }^{138}$ But those remedies have little applicability to industrial espionage. ${ }^{139}$ Recognition of the corporate right of privacy would simply be a means for society to implement its goals by providing a defensive shield to the offensive thrusts of the commercial pirate. ${ }^{140}$ Such recognition would, moreover, allow the courts to meet the wrong

One who has established a cause of action for invasion of his privacy is entitled to recover damages for

(a) The harm to his interest in privacy resulting from the invasion.

...

(c) Special damage of which the invasion is the legal cause.

See also ProsSER $\S 112$.

135. HOFSTADER \& HoROwitz $\$ 24.4$.

136. See notes 6, 19 supra and accompanying text.

137. Industrial Espionage 926.

138. See note 9 supra and accompanying text.

139. See notes 77-106 supra and accompanying text.

140. The right of privacy has historically grown in response to the other developments of society. As new means have been devised to offend the interests of privacy, the right of privacy has been the defensive means by which the offensive challenge has been deflected. See Nizer, supra note 31, at 559. 
head-on without perversion of existing doctrine to cover contingencies for which it was not designed.

\section{Corporate Privacy - Its Advocacy and Existence}

In advocating that the corporate right of privacy should be recognized as a means of protecting the victims of industrial espionage, one might proceed upon either of two theories. It might be argued, in light of the demonstrable inapplicability of existing forms of action to industrial espionage activity, that there is a present need for its creation. On the other hand, it could be contended, in view of the many instances in which corporations are already granted forms of privacy protection, that the corporate right of privacy already exists and should simply be made available to the industrial espionage victim. In terms of the historical development of the right of privacy it is more accurate to argue that the corporate right of privacy already exists-this approach found immediate judicial favor when utilized by Warren and Brandeis. ${ }^{141}$

One of the leading commentators in the trade secret field has conceptualized a zone of corporate activity termed a "secret sphere" around which the law has placed a protective veil. 142 This type of analogy is a convenient means of expressing the view that the corporation already enjoys the protection of an actual, if unarticulated; right of privacy with regard to several areas of its corporate existence. Beyond those "privacy areas" which have already been discussed, ${ }^{143}$ a corporate right of privacy is also indicated by the availability of the judicial doctrines protecting commercial secrets. ${ }^{144}$ There has been much groping for a principle upon which to

141. See notes 33-45 supra and accompanying text.

142. 2 Callmann $\S \S 51.1,56$. "It constitutes . . . an invasion of the secret sphere . . . for the competitor to attempt to ascertain the trade secret [improperly]. . . " /d. $\S 56$.

143. Thus, it has been noted that the attorney-client and other evidentiary privileges allow the corporation a right to maintain its correspondence in secret, a privilege which has been identified as an incident of a right of privacy. See notes $111-19$ supra and accompanying text. Similarly, corporations are accorded a right to prevent the commercial appropriation of their name or reputation, a right which is also described as privacy protection. See notes 120-23 supra and accompanying text. For the legislative conclusion that the corporation is extended this type of privacy protection, see UTAH CODE ANN. \& 76-4-9 (Supp. 1969), which provides in pertinent part as follows:

Any living person .... whose namc, portrait or picture is used . . . for advertising purposes . . . and, any person or corporation may maintain an action against a violator . . . It shall not be necessary that actual damages to the plaintiff be alleged or proved

...

144. These doctrines are discussed at notes 70-85 supra. 
ground this protection, ${ }^{145}$ but it would appear to stem in substantial part from a premise of privacy protection. ${ }^{146}$ Where common law trade secret remedies are applied, that which is accorded protection cannot be the unpatented information itself, since that would violate the spirit of the patent laws. ${ }^{147}$ Rather, the corporation is allowed to maintain its secrets free from the inquisitive eyes of its competitors on the same basis that it is able to maintain its correspondence free from fellow-litigants and its name and identity from the commercial use of others - upon a premise that the corporation does in fact have a "secret sphere" of privacy around which the law has placed a veil of protection. ${ }^{148}$ Thus, when commercial intelligence agents seize a corporation's secrets, the law punishes not the compromise of the secret, but the violation of the privacy sphere by the use of improper means. The limited nature of the legal sanction applied to intrusions upon the "secret sphere"-punishing only wrongful conduct-is not, however, inconsistent with the right of privacy concept. The individual is given no absolute right to keep his feelings, thoughts, and emotions secret. He is, rather, required to temper his interest in privacy with those societal interests with which it conflicts. ${ }^{149}$ This is similar to the limited protection allowed by the trade secret remedy. In both

145. 2 CallmanN $\S 51.1$; Warren \& Brandeis 212.

146. This has been the implicit view of several commentators. See, e.g., WESTIN 334; Stedman 23. Warren and Brandeis also used the trade secret doctrine as an example of the application of the right of privacy. Warren \& Brandeis 212.

In Waring v. WDAS Broadcasting Station, 327 Pa. 433, 194 A. 631 (1937), plaintiff orchestra conductor, whom the court considered to represent the corporate form of the orchestra, had made recordings and when these were played over defendant's radio station, plaintiff sought an injunction. The concurring judge concluded that the ground of relief should be the right of privacy, citing the Warren and Brandeis article. Id. at 458, $194 \mathrm{~A}$. at 643 (Maxey, J., concurring). Thus, Waring could be read, at least in its concurring opinion, as recognizing the existence of a corporate right of privacy. See also E.I. duPont deNemours \& Co. v. Christopher, 431 F.2d 1012 (5th Cir. 1970).

147. The policy of the patent law precludes the protection of articles for which no patent has been obtained. Sears, Roebuck \& Co. v. Stiffel Co., 376 U.S. 225, 231 (1964). The preemption of the federal patent laws is discussed in detail at notes 167-209 infra.

148. 2 Callmann $\S 51.1$.

149. This fact was recognized by Warren and Brandeis, who provided a list of limitations upon the right of privacy. Warren \& Brandeis 214-20. The Supreme Court has also reiterated the proposition that the right of privacy is a limited right. In Time, lnc. v. Hill, 385 U.S. 374 (1967), the Court extcnsively discussed such limitations and noted that "constitutional protections for speech and press preclude. . . [punishment for] false reports of matters of public interest in the absence of proof that the defendant [who had been sued under the New York right of privacy statute-N.Y. Civ. Rights LAw $\S \S 50-51$ (McKinney 1948)] published the report with knowledge of its falsity or in reckless disregard of the truth." 385 U.S. at 387-88. 
instances one is initially accorded a broad right of protection, which is then reduced in compliance with the dictates of a free society and a free economy.

Perhaps the most salient evidence that corporate privacy is a viable concept is found in two recent legal developments. The first is the inclusion of corporations in the expanding wave of eavesdropping statutes which are evolving to protect the public from the encroachments of surreptitious surveillance. These statutes provide broadly that it is unlawful to employ eavesdropping devices for the purpose of overhearing conversations or clandestinely observing business operations. ${ }^{150}$ It is clear from the language ${ }^{151}$ and the legislative history ${ }^{152}$ of the statutes that they were designed to protect

150. The Miehigan statute covers "[a]ny person who installs in any private place, without the consent of the person or persons entitled to privacy there, any device for observing. photographing or eavesdropping upon the sounds or events of such place . . . ." Mic11. COMP. Laws ANN. § 750.539(d) (1968). See also Alaska Stat. § 11.60 .290 (1970); Arizona Rev. Stat. Ann. \$13-1051 et seq. (Supp. 1970); Conn. Gen. Stat. Ann., Penal Code $\$ 189$ et seq. (Pamphlet Supp. 1971); Fla. STAT. ANN. \$934.01 et seq. (Supp. 1970); GA. Code ANN. $\$ 26-300$ l et seq. (Supp. 1970); Hawall REv. LAws $\$ 275-1$ et seq. (1968); I l.t. ANN. Stat. ch. 38, § 14-1 et seq. (Smith-Hurd 1964); Kansas STAT. ANN. § 21-4001 et seq. (Supp. 1969); Mass. AnN. Laws ch. 272, $\S 99$ et seq. (Supp. 1970); MinN. Stat. ANn. $\$ 626 A .01$ ct seq. (Supp. 1971); MONT. Rev. Codes ANN. § 94-35-274 (1969); N.H. Rev. Stat. AnN. § 570-A:1 et seq. (Supp. 1970); N.Y. Penal. Law $\S 250.00$ et seq. (McKinney 1967); R.1. GeN. Laws ANN. \& 11-35-21 et seq. (Supp. 1970).

A similar act was introduced in the 90th Congress, entitled the Right of Privacy Act of 1967, S. 928, 90th Cong., 1st Sess. (1967), which provided, inter alia, that:

$\S 2511$. Eavesdropping.

(a) Any person who. . . willfully uses or attempts to use any electronic, mechanical or other device for the purpose of eavesdropping. . . when-

(4) such use or attempted use (A) takes place on the premises of any business or other commercial establishment ... ; or (B) obtains or is for the purpose of obtaining information relating to the operations of any business or other commercial establishment....

See Hearings on $S .928$, pts. 1 \& 2 . The present federal law prohibiting eavesdropping is contained in 18 U.S.C. $\$ 2510$ et seq (Supp. V, 1970).

It might be noted that one probably unanticipated side effect of these statutes may be to prevent the possession, by a supposed industrial espionage victim, of electronic device detection equipment. See Milgrim $\S 5.05$, at 75 (Supp. 1971).

151. That the statutes are designed to protect privacy rights is clear from their language. Thus, one statute makes it a violation for "any person to commit . . . acts . . . which invade the privacy of another." GA. Code ANN. § 26-3001(f) (Supp. 1970). Another notes that "persons entitled to privacy" are protccted. Mich. COMP. LAwS ANN. § 750.539(d) (1968). See also Fla. Stat. AnN. $\$ 934.01(2)$ (Supp. 1970); Nev. Rev. Stat. $\$ 200.650$ (1969). Scveral of the statutes are specifically entitled as dealing with "privacy." See GA. CoDE ANN. \$§ 26-3001 et seq. (Supp. 1970); MinN. Stat. ANN. § 626A.01 et seq. (Supp. 1971).

152. See, e.g., Hearings on S. 928, at 610-11, which contains the report of the Georgia legislature. 
the privacy interests of those against whom the evils of eavesdropping are directed, including the privacy of businesses subject to industrial espionage. ${ }^{153}$ These statutes are uniformly criminal in nature, ${ }^{154}$ but the provision of civil remedies in several is indicative of the fact that they were intended not only to punish the wrongdoer but to provide a privacy remedy to the wronged party as well. ${ }^{155}$ The inclusion of corporations within the sweep of this statutory privacy coverage ${ }^{156}$ is persuasive evidence of the current vitality of the corporate right of privacy, especially as regards the consequences of industrial espionage. ${ }^{157}$

153. In the Report of the Invasion of Privacy Study Committee of the Georgia legislature the following findings were recited:

The use of these [surveillance] devices in the field of industrial espionage, stealing of trade secrets . . . and other private investigation purposes has been made well known.

....

It was determined by the Committee tbat the necessity of the protection of the privacy and elimination of growing practices of snooping and spying requires a new comprehensive statute ... [to protect] the individual's privacy and end the serious intrusion of personal and business privacy.

Id. (emphasis added).

154. Several of the statutes deem eavesdropping a felony. Ariz. Rev. Stat. ANn. § 13-1052 (Supp. 1970); Conn. Gen. Stat. Ann. $\$ 191$ (Penal Code Oct. 1971); Mich. Comp. Laws ANN. $\$ 750.539$ (c) (1968). Others make it a misdemeanor. Alaska Rev. Stat. ANN. $\S 11.60 .310$ (1970); Kansas Stat. AnN. § 21-4001 (Supp. 1969); Moñr. Rev. Codes ANN. § 94-35-274 (1969).

155. Where a civil remedy is allowed, it consists of relief by injunction or actual or punitive damages. See 18 U.S.C. $\$ 2520$ (Supp. V, 1970); Fla. STat. AN. § 934.10 (Supp. 1970); IlL. ANN. Stat. ch. 38, § 14-6 (Smitb-Hurd 1969); Mich. CoMp. LAws ANN. § 750.539(h) (1968); Minn. Stat. ANN. \& 626A.13 (Supp. 1970); N.H. Rev. Stat. ANN. § 570-A:11 (Supp. 1970). See also Proposed Final Draft for Standards Relating to Electronic Surveillance, A BA PROJECT on Standards for CRIMinal Justice $\S 2.2$ (197I).

156. Georgia, for example, provides that the invasion of the privacy of "another" by surveillance or eavesdropping is punishable. GA. Code ANN. § 26-3001 (Supp. 1970). "[A]nother" is defined as a "person," id. $\S 26-401(\mathrm{c})$, while "person" is defined as "an individual, a public or private corporation . . ." Id. $\S 26-401(1)$. See also Hearings on S. 928, at 610-11.

157. It could, of course, be asked why a common law privacy right should be recognized when there already exists statutory privacy protection against industrial espionage. The question is to be answered by observing that, not only do most jurisdictions still lack sucb eavesdropping statutes, but also that where they do exist many do not on their face apply to corporations. The statutes are also uniformly criminal in nature, with only a small percentage providing a civil rcmedy. Finally, the coverage of the statutes seems directed at only the eavesdropping and wiretapping aspects of industrial espionage activity and does not provide a remedy against aerial photographic surveillance as was involved in Christopher, discussed at notes 96-105 supra and notes $158-66 \mathrm{infra}$. They also do not provide a remedy against the spy in the victim's employ. See note 79 supra. Thus, despite the existence of these statutory remedies, there is still a need for the judicial recognition of a common law corporate right of privacy. 
The second significant development is the recent decision of the Fifth Circuit in E.I. duPont deNemours \& Co. v. Christopher. ${ }^{158}$ As has already been noted, that case involved the acquisition of a secret process by aerial photography, an action which has been seen to be subject to none of the existing remedies for trade secret theft. ${ }^{159}$ Implicitly recognizing this lack of coverage, the court in Christopher chose to recognize a corporate right of privacy rather than to pervert traditional theory. The court declared that in light of the current tendency of the law to enforce higher standards of commercial morality in the business world, trade secret protection should not be limited to traditional doctrinal bases of relief. ${ }^{160}$ Accordingly, the court concluded that the invasion of commercial privacy is actionable and that aerial photography of commercial secrets constituted a forbidden invasion. ${ }^{161}$

The significant future issues raised by Christopher may be essentially resolved by examining the question of what test is applied to determine a violation of the "commercial privacy" of the espionage victim. The test articulated by the Fifth Circuit might be stated as follows: if espionage could not be prevented because the cost of necessary protections would be unreasonable, or if the invasion is such as to be unanticipated and to preclude self-protection, then the acts of the competitor violate the owner's right of commercial privacy. ${ }^{162}$ This test is likely to become the cornerstone of future industrial espionage cases, a result which will place a far different complexion upon the business surveillance practice. ${ }^{163}$

158. 43! F.2d 1012 (5th Cir. 1970).

159. See notes 99-104 supra and accompanying text.

160. $431 \mathrm{~F} .2 \mathrm{~d}$ at 1015 . This is consistent with the original view of the Restatement of Torts that improper means of discovery "are means which fall below the generally accepted standards of commercial morality and reasonable conduct." RESTATEMENT OF TORTS $\$ 757$, comment $p$ (1939).

161. The words of the court in Christopher are persuasive as to why there must be a corporate right of privacy:

[I]ndustrial espionage of the sort here perpetrated has become a popular sport . . . . However, our devotion to free wheeling competition must not force us to accepting the law of the jungle as the standard of morality . . . Our tolerance of the espionage game must cease when the protections required to prevent another's spying cost so much that the spirit of inventiveness is dampened. Commercial privacy must be protected from espionage which could not have been reasonably anticipated or prevented. . . .

We introduce here no new or radical ethic since our ethos has never given moral sanction to piracy. 431 F.2d at 1016. (Emphasis added.)

162. Id. at 1016.

163. Specifically, the court said "thou shall not appropriate a trade secrct through 
In light of Christopher, the privacy-protecting eavesdropping statutes, and the other reflections of a corporate "privacy sphere" created by law, ${ }^{164}$ it is believed that the corporate right of privacy already exists, ${ }^{165}$ ready for application to specific future industrial espionage events. ${ }^{166}$

\section{Preemption by Federal Patent Policy}

Although substantial authority supports the contention that a corporate right of privacy already exists to protect the victims of industrial espionage, the spreading shadow of the federal patent law, as enunciated in three recent Supreme Court decisions, may be argued to have preempted any judicial protection of unpatented information. To determine the force of this preemption and its effect upon the present analysis, it is necessary to review those decisions and their progeny in some detail.

\section{The Decisions}

In Sears, Roebuck \& Co. v. Stiffel Co. ${ }^{167}$ and Compco Corp. v. Day-Brite Lighting, Inc. ${ }^{168}$ the Supreme Court dealt with the Illinois law of unfair competition. In Sears Stiffel had been granted patents on a pole lamp. Thereafter, Sears made an identical copy of the lamp and sold it at a lower price whereupon Stiffel brought an action for patent infringement and unfair competition. Although the lower court found the patents invalid, it held that Sears' copying violated the state

deviousness under circumstances in which countervailing defenses are not reasonably available." Id. at 1017.

164. One might additionally argue that as a consequence of NAACP v. Alabama, 357 U.S. 449 (1958), there is a residual right of associational privaey. In that case the Supreme Court stated that the inviolability of group association may in many circumstances be essential to preservation of associational rights. Id. at 462 . Although one might seek to extrapolate that decision into the present context, such a position is unneeessary in light of the other bases herein discussed and is specifically not relied upon as a basis for the envisioned right of privacy as a remedy for the victim of industrial espionăge. See Harris, supra note 125.

165. It has been predicted by one prominent observer of the law of privacy that the courts will soon accord right of privacy protection to corporations. "In brief and in conclusion, new law to protect the 'private' feelings of corporations and institutions is developing, and 1 make bold to suggest that the New York Court of Appeals may well . . . add 'a new chapter to the law.' " Horowitz, supra note 59, at 108.

166. Remarking upon tbe combined effect of Christopher and other developments in the law of privacy, it bas been noted that the industrial spy may be entering a period of greater risk as the privacy law develops. MiLGRIM § 5.05, at 75 (Supp. 1971).

167. 376 U.S. 225 (1964).

168. 376 U.S. 234 (1964). 
unfair competition laws. The Supreme Court reversed, holding the Illinois unfair competition law incompatible with the federal patent laws. Justice Black, for the Court, predicated the decision on the "familiar doctrine" that when a state law touches upon federal statutory patent law it must yield. ${ }^{169}$ To substantiate his proposition that absent a patent right an article could receive no judicial protection, Justice Black noted that when a patent is issued a statutory monopoly is allowed and when the patent expires so does the monopoly, the rights therein passing to the public. ${ }^{170}$ In the present case, the Court declared that since greater protection should not be given an unpatented article than one upon which a patent has expired, Stiffel's unpatented lamp was in the "public domain" and subject to a public right to copy. ${ }^{171}$ The lower court's allowance of an unfair competition award, therefore, conflicted with the objectives of the federal patent laws, since it gave Stiffel the equivalent of an unlimited monopoly on an unpatented article. ${ }^{172}$

Compco involved a similar situation. Day-Brite had developed a distinctive design for the cross-ribbing of fluorescent lighting fixtures. Having failed to gain a patent of its own, Compco nevertheless produced the same article, precipitating suit by Day-Brite for patent infringement and unfair competition. The district court held the patent invalid, but found Compco guilty of the unfair competition charge since similarity of the items was likely to cause confusion. ${ }^{173}$ Justice Black, in reversing, noted that such a holding was contrary to federal patent policy allowing free copying of whatever the federal patent or copyright laws left in the "public domain," such as DayBrite's unpatented fixtures. ${ }^{174}$

169. "[T]he federal policy 'may not be set at naught, or its effects denied" by the state law." 376 U.S. at 229. The language of the Court is probably somewhat broad as respects the scope of preemption when state and federal acts interfere. See 1 Callmann $\$ 11.2(a)$.

170. 376 U.S. at 230.

171. Id. at 231. It is interesting to note that 25 years prior to Sears the Restatement of Torts noted that, absent a breach of contract, abuse of confidence, or improper means of discovery, a trade secret could be freely copied. RESTATEMENT OF TORTS $\$ 757$, comment $a$ at 4 (1939). See also American Harley Corp. v. Irvin Indus., Inc., 27 N.Y.2d I68, 179, 263 N.E.2d 552, 557, 315 N.Y.S.2d I29, 136, (1970) (Breitel, J., concurring). The scope of the "public domain" is discussed at note 193 infra.

172. 376 U.S. at 233. The Court said that "the patent system is one in which uniform federal standards are carefully used to promote invention while at the same time preserving free competition." Id. at 230-31.

173. The decision premised upon likelihood of confusion has reference to the "palming off" doctrine, another of the constitutents of the unfair competition doctrine, which was discussed in Sears. 376 U.S. at 227 n.2. See I Callmann $\S 4.1$; Nims $\S 9$ a.

174. 376 U.S. $234,237-38$. 
Although the specter of preemption has caused much "conjecture and reverberation" 175 in the area of trade secrets, its full scope has not as yet been completely delineated. Taken literally, Sears and Compco seem to say that the protection of an un-patented commercial secret conflicts with and undermines the federal patent laws. A literal application of that broad rule to the law of trade secrets arguably preempts state-created trade secret protection. ${ }^{176}$ Such construction has not, however, been adopted by lower courts. ${ }^{177}$ The preemption has been confined in effect to the copying of articles in the public domain and rejected as to items held in secrecy. ${ }^{178}$ Preemption has also not been extended to the punishment of misappropriation ${ }^{179}$ or to the breach of confidence action. ${ }^{180}$ Perhaps most importantly for present purposes, Sears and Compco have been held inapplicable to industrial espionage ${ }^{181}$ or other usages of improper means. ${ }^{182}$ Sears and Compco

175. MiLGRIM § 7.08[2][c].

176. Whether Sears and Compco have preempted the common law body of trade secret rules has been a fertile subject of inquiry. See 2 Callmann $\$ 53.2(\mathrm{~b})$; Milgrim $\S 7.08$ [2]; Adelman, Trade Secrets and Federal Pre-emption-Aftermath of Sears \& Compco, 49 J. PAT. OFF. Soc'Y 713, 715 (1967); Doerfer, supra note 79, at 1461-62; Peterson, supra note 8, at 35863; Note, The Trade Secret Quagmire-A Proposed Federal Solution, 50 MinN. L. Rev. 1049 (1966); Note, Doctrine of Licensee Estoppel Overruled; State Protection of Unpatented Inventions Questioned-Lear, Inc. v. Adkins, 45 N.Y.U.L. Rev 386, 391 (I970); Note, The Stiffel Doctrine and the Law of Trade Secrets, 62 Nw. U.L. Rev. 596 (1968).

177. Hampton v. Blair Mfg. Co., 374 F.2d 969 (8th Cir. 1967); Servo Corp. of America v. General Elec. Co., 337 F.2d 716 (4th Cir. 1964), cert. denied, 383 U.S. 934 (1966); Schulenberg v. Signatrol, Inc., 33 1II. 2d 379, 212 N.E.2d 805 (1965); 2 CallmanN $§ 53.2(b) ;$ MiLgrim \& 7.08[2]; Bender 919; Hawkland, Some Recent American Developments in the Protection of Know How, 20 Buffalo L. Rev. 119, 134 (1970);Note, Trade Secrel Law After Sears and Compco, 53 VA. L. Rev. 356 (1967); 45 N.Y.U.L. Rev., supra note 176, at 393. The Schulenberg case was distinguished in Bimba Mfg. Co. v. Starz Cylinder Co., 119 11l. App. 2d 25I, 256 N.E.2d 357 (1969), where no trade secret was involved.

178. Water Servs., Inc. v. Tesco Chems., Inc., 410 F.2d 163 (5th Cir. 1969). The court noted that Sears and Compco do not apply to trade secrets which are not on the open market. Id. at 171.

179. See 53 VA. L. Rev., supra note 177 , at $359-63$. The misappropriation doctrine is discussed at note 78 supra.

180. Water Servs., Inc. v. Tesco Chems., Inc., 410 F.2d 163 (5th Cir. 1969); Servo Corp. of America v. General Elec. Co., 337 F.2d 716, 723-24 (4th Cir. 1964); Bender 919-2I.

18I. Schulenberg v. Signatrol, Inc., 33 ill. 2d 379, 212 N.E.2d 865 (1965). The court noted that "[i]t is readily apparent that the Sears and Compco cases do not cover a situation of industrial espionage by employees who plan to organize a competing company and thereafter do that very thing." Id. at 386, 212 N.E.2d at 869. This view of Sears and Compco is, moreover, in harmony with the opinion of Mr. Justice Harlan, concurring in both Sears and Compco, who noted that vindication of federal interests does not require the toleration of predatory business practices. 376 U.S. at 239.

182. Bender, supra note 9, at 919. 
may thus be seen to have been restrictively construed, and, in response to the clamor of the commentators, found inapplicable to preempt the laws of trade secret protection. ${ }^{183}$ Even given this narrow construction, however, one must remember that the Supreme Court has served notice that it will reject any decision which frustrates or conflicts with the patent law whether it be based upon trade secret or other protective doctrines. ${ }^{184}$

The Supreme Court, however, has not been content to let the Sears and Compco preemption rule have a "decent interment." In Lear, Inc. $v$. Adkins ${ }^{185}$ an engineer had been hired to help solve gyroscope problems and agreed to grant his employer a license on all of the inventions he developed. After discovering a production method which improved the gyros, the engineer filed for a patent and, prior to patent approval, licensed the innovation to Lear. Before the patent was finally issued, Lear terminated its payment of royalties, claiming that the improvement had been fully anticipated by an existing patent. When a patent was finally issued, the engineer brought suit. The California Supreme Court held, with regard to the pre-patent California license, that Lear was estopped by its licensee agreement from questioning the patent. ${ }^{186}$ Upon appeal, the principal issue was the vitality of the venerable doctrine of patent licensee estoppel, ${ }^{187}$ which the Supreme Court repudiated in reversing the California decision. ${ }^{188}$

183. 2 CallmanN $\S 53.2(b)$; Milgrim $\S 7.08[2]$ ] 45 N.Y.U.L. Rev., supra note 176, at $391-93$.

184. 2 CALLMAN $\$ 53.2(\mathrm{~b})$. It is, however, often repeated that there is no conflict between the patent and trade secret laws. Id. 45 N.Y.U.L. REV., supra note 176, at 395; 53 VA. L. REV., supra note 177 , at 371 .

185. 395 U.S. 653 (1968).

186. 67 Cal. 2d 882, 435 P.2d 321, 64 Cal. Rptr. 545 (1967)

187. Estoppel hasmost often arisen in two distinct but closely related situations . . . . In an assignment of a patent the inventor ostensibly transfers . . . all rights under his patent. . . . If after the assignment the inventor commences or continues to manufacture the patented device, . . . the inventor may not defend on the basis that his invention was invalidly patented. A patent license .... is a transfer . . . of a limited right. . . . A patent license is a contract, and a cause of action thereunder will normally arise . . . if the licensee breaches . . . . In the past, courts have refused to permit a licensee to assert the invalidity of the licensed patent when he is sued for non-payment of royalties. Note, "Decent Burial" of Patent Licensee Estoppel, 1970 Duke L.J. 375-76.

See also Tiokol Chem. Corp. v. Burlington Indus., Inc., 313 F. Supp. 253, 255 (D. Del. 1970).

188. In reversing, the Court felt required to accommodate the competing demands of the common law of contracts and the federal patent laws, which involved precluding breach of promise on the one hand and facilitating the dissemination of information on the other. 395 U.S. at 668 . The holding of Lear would, however, apparently be overruled by a pending bill 
Although Lear is primarily important for its repudiation of the estoppel rule, ${ }^{189}$ for present purposes the Court's discussion of the licensing of unpatented inventions is particularly significant. The Court found that Lear squarely raised the question of whether, in light of the patent laws, the states may accord protection to the owners of unpatented discoveries which are disclosed to others for the payment of royalties. ${ }^{190}$ This issue is particularly crucial to the law of trade secrets because such contractual arrangements are the basic means by which trade secrets are disseminated to non-owners and by which an owner protects himself against disclosure by those to whom he divulges secrets in confidence. ${ }^{191}$ Licensing has not in the past been viewed as bringing the trade secret into the public domain, ${ }^{192}$ and the question raised by the Court in Lear goes to the heart of that theory. Specifically, the question raised by Lear is whether the patent preemption enunciated in Sears and Compco prohibits the protection of secrets which are not the subject of patent rights and which are not otherwise in the public domain. ${ }^{193}$ Although the Court chose to leave

introduced by Senator McClellan, S. 643, 92d Cong., lst Sess. (1971), which is discussed at note 209 infra. See MILGRIM $§ 7.08[2]$ n.56.27.

189. See generally MILGRIM $§ 7.08[2] ; 1970$ DUKE L.J., supra note 187; 45 N.Y.U.L. REV., supra note 176.

190. 395 U.S. at 674. The Court also phrased the question as whether "federal law requires that all ideas in general circulation be dedicated to the common good unless they are protected by a valid patent." Id. at 668. See MILGRIM $\S 7.08[2]$.

191. MILGRIM $\S \S 3.02,3.05[3]$; Bender 920; Klein 446. See the discussion in Water Servs., Inc. v. Tesco Chems., Inc., 410 F.2d 163, 170-71 (5th Cir. 1969).

192. 2 CallmanN $\S \S 52.1,53.3$ (d).

193. Inasmuch as the patent preemption doctrine enunciated in Sears applied only to articles in the "public domain," it could be argued, in light of the lower court construction placed upon the scope of the preemption, notes 176-84 supra, that the "public domain" includes only those articles not held in secrecy. Arguably, this view could be supported by the language of the Court in Lear that the "federal law requires that all ideas in general circulation be dedicated to the common good unless they are protected by a valid patent." 395 U.S. at 668 (citing Sears and Compco) (emphasis added). It could also be supported by the fact that the articles in both Sears and Compco were in "general circulation." In view of the broad language he used in Sears and Compco and in his Lear concurrence-dissent, Justice Black, however, implies that all inventions are in the public domain as an initial matter-a view supported by Painton \& Co. v. Bourns, Inc., 309 F. Supp. 271 (S.D.N.Y. 1970), rev'd and rem'd, F.2d (2d Cir. 1971). If this view prevails, it will cut to the heart of the trade secret protection. Adelman \& Jaress, Inventions and the Law of Trade Secrets After Lear, Inc. v. Adkins, 16 WAyne L. Rev. 77, 84 (1969). See also 45 N.Y.U.L. REV., supra note 176 at $387-91$.

To eliminate the spectre of Lear over the trade secret law congressional action has been taken both to establish a federal law of trade secrets and to restrict the scope of patent policy preemption. See notes 209 \& 217 infra.

It should be noted that the issues here discussed were not the subject of either brief or oral argument in the presentation of Lear before the Supreme Court. M!LGRIM $\S 7.08$ [2]. 
the question open, ${ }^{194}$ it did say that the issue, unsettled in a hundred years of case law, ${ }^{195}$ should now be adjudicated. ${ }^{196}$

The ultimate effect of the unanswered question in Lear upon the scope of the patent preemption policies is, at this point, a subject which is open to considerable conjecture, and its ultimate resolution has generated a great deal of controversy. ${ }^{197}$ The potential effect of Lear upon the patent preemption doctrine could follow either of two polar courses. It might, first of all, be found to have reiterated the literal meaning of the language of Sears and Compco so as to entirely preempt the state trade secret doctrines, a result resoundingly rejected by the original judicial construction of those cases. Alternatively, Lear might be distinguished to the extent that its "non-holding" would not alter the premption doctrine as previously interpreted. ${ }^{198}$ In view of the facts of Lear, it is not unlikely that federal patent preemption may now extend to the protection of secrets not heretofore deemed to be in the public domain, particularly secrets disclosed in confidence since a licensee arrangement has in the past been considered a relation of confidence. ${ }^{199}$ Such construction would, of course, essentially preempt the traditional trade secret doctrine.

194. This question was considered, in a separate opinion by Justices Warren, Douglas, and Black to have already been decided in the affirmative by Sears and Compco. 395 U.S. at 677. Mr. Justice Black observed that

[n]o State has a right to authorize any kind of monopoly on what is claimed to be a new invention, except when a patent has been obtained . . . [P]rivate arrangements under which self-styled "inventors" . . disclose [their inventions], in return for contractual payments run counter to the plan of our patent laws. . . . The national policy ... favoring free competition and narrowly limiting monopoly, cannot be frustrated by private agreements among individuals, with or without the approval of the State. Id. at 677.

Whether Sears and Compco in fact answered the question is open to considerable dispute. See Wetzel \& Niro, The Look of Lear-An Advocate's View, 45 Notre Dame Law. 475, 482 (1971). The question was again raised in subsequent litigation. Adkins v. United States Dist. Ct., 431 F.2d 859, 860 (9th Cir. 1970). The failure of the Court to decide the question "seems designed to continue . . . the controversy initiated . . ." by Sears and Compco. 45 N.Y.U.L. REv., supra note 176, at 391.

195. MiLGRIM § 7.08[2][c].

196. 395 U.S. at 674-75. The Court also observed that "it is impossible to predict the extent to which this re-evaluation will revolutionize the law . . ." Id. at 675 (emphasis added). One writer has expressed the belief that in this part of the opinion the Court has indicated that the law of trade secrets has a very questionable future vitality. Bender 921. See also MiLGRIM \& 7.08[2].

197. A compilation of citations is in MiLGRIM $\S 7.08[2] \mathrm{nn} .56 .19,56.22 ; 45$ N.Y.U.L. REv., supra note 176.

198. MILGRIM \& 7.08[2], at 7-70.2.

199. See note 80 supra and accompanying text. One commentator, however, differentiating among various confidence relationships, acknowledges that Lear may apply to licensing 
Upon the rendering of the Lear decision, a portent of doom was forecast for the future vitality of the trade secret law, premised upon the fear that Lear had reaffirmed the broadest of possible scopes for the patent preemption. ${ }^{200}$ This prediction has, unfortunately, been "more prophetic than would have been hoped." 201 The one case which has reached the question of the breadth of the post-Lear preemption doctrine has applied it to the trade secret area. In Painton \& Co. v. Bourns, Inc., ${ }^{202}$ the issue was whether a trade secret licensee was required to pay royalties under an expired licensing contract on models for which no patent application had been or would be made. The district court, relying on Lear, held that protection would violate federal patent policy, and that under applicable state law the licensee could continue its manufacture despite termination of the licensing contract. Particularly noteworthy is the court's discussion of the combined effect of Sears, Compco, and Lear upon the law of trade secrets. The court noted that the strict requirements of the patent laws would be weakened if an inventor could enforce protective contracts for allegedly secret ideas without submitting them for patent analysis. ${ }^{203}$ Such allowance would cause the "severely restricted area" left open by the Supreme Court to become a "yawning abyss." ${ }^{204}$ For

arrangements but would not apply to the employer-employee situation. "An employee may be found to be in closer privity with the owner of the secret than is the licensee. Also, the abolition of trade secret protection in the employee-employer case would seem innately to deprive a person of his 'right' to keep his secret-as opposed to licensing it for compensation." Bender 921 . Mr. Bender also proposes a means of applying Lear to the law of trade secrets so as to minimize its preemptive injury. Id. 92I-26. It will be noted that Sears and Compco were construed as inapplicable to relations of confidence. See note 179 supra. Thus, it could be concluded that the operative effect of Lear will be to limit further the confidential relationships to which the preemptive force of the patent laws will not apply.

200. MiLGRIM $\S 7.08$ [2]. See also Wetzel \& Niro, supra note 194, at 484.

201. MiLGRIM $\S 7.08[2]$, at 7-70.6.

202. 309 F. Supp. 27 I (S.D.N.Y. 1970), rev'd and remanded, F.2d (2d Cir. 1971). The district court opinion was criticized in Milgrim, Sears to Lear to Painton: Of Whales and Other Matters, 46 N.Y.U.L. REv. 17 (1971); 84 HARV. L. REV. 477 (1970), and was appropriately described as "the first offspring of the preemption dragon . . . ." Bender 922.

203. 309 F. Supp. at 274.

This court's enforcement of such an agreement would be contrary to our national patent law and policy ... . Our patent policy of strict regulation of inventions would be undercut if inventors could enforce agreements for compensation for alleged secret ideas without being required to submit those ideas to the Patent Office, and, thereby, eventually have the ideas disclosed to the public. Id.

Painton, it may be noted, actually decided only the narrowest question left open by Lear-the licensing of non-patented articles. Whether or not this preemption would also restrict remedies for conduct which would previously have been punished as wrongful discovery of a non-patented article, however, is still an open and disputed question.

204. 309 F. Supp. at 274. 
these reasons, the court observed that the "federal patent law requires an inventor to submit his ideas to the Patent Office before . . . [they will be protected]...."205

If cases consistent with Painton \& Co. typify the "wake" of Lear as to the future scope of the preemption doctrine, it is fairly clear that the law of trade secrets will be reduced to a shambles. Such a result, however, has been met with a resounding "hue and cry"-including reversal by the Second Circuit of the district court in Painton \& Co. ${ }^{206}$ As courts thus consider the interests and policies underlying trade secret protection, ${ }^{207}$ it is likely that Lear will have only slight effect upon the restrictive application already given the Sears and Compco preemption. ${ }^{208}$ This result would be consistent with the contemporary wisdom of trade secret commentary. Whatever the future application of Lear, however, it is apparent that, subject to reinterpretation by the Supreme Court, the combined impact of Sears, Compco, and Lear makes the continued application of the unfair competition and trade secret doctrines to the protection of non-patented commercial secrets somewhat problematic. ${ }^{209}$

205. Id. A similar result was reached in Bimba Mfg. Co. v. Starz Cylinder Co., 119 11l. App. 2d 251, 256 N.E.2d 357 (1969), citing Lear, where an injunction and damage award predicated solely upon the departing employee's copying of a non-trade seeret article was held to be in conflict with the federal patent laws. Id. at 271,256 N.E.2d at 367.

206. Painton \& Co. v. Bourns, Inc., F.2d (2d Cir. 197I). See Milgrim § 7.08[2], at 7-70.7; Adelman \& Jaress, supra note 193, at 93; Arnold \& Goldstein, Life Under Lear, 48 TeXAS L. Rev. 1235, 1260 (1970); Bender 923; Milgrim, supra note 202; 1970 DuKE L.J., supra note 187 , at 389-90; 45 N.Y.U.L. REV., supra note 176, at 391-94.

207. For a discussion of some of these policies, see 45 N.Y.U.L. Rev., supra note 176, at 393-96.

208. In reversing the district court in Painton, Judge Friendly discussed in some detail the interrelation of Sears, Compco, and Lear, and the trade secret doctrines. Painton \& Co. v. Bourns, Inc., F.2d , (2d Cir. 1971). It has been noted that the construction of Lear has not disturbed the prior construction of the Sears and Compco premption. Comment, The Viability of Trade Secret Protection After Lear v. Adkins, 16 VILL. L. Rev. 551, 568-69 (1971). See also Bendix Corp. v. Balax, Inc., 421 F.2d 809, 821 (7th Cir. 1970).

209. 2 Callman $\S 53.2$ (b). Lear might, of course, be reversed by congressional action, without waiting for the Supreme Court to reconsider the practical effects of an overly broad preemptive patent policy. The practical consequences of Lear are discussed in 45 N.Y.U.L. REV., supra note 176, at 392-96. Such a legislative reversal has apparently already been initiated. Senator McClellan has introduced a bill in the $92 \mathrm{~d}$ Congress which appears to overrule any possible extension by Lear of patent policy preemption into other areas, such as trade secrets, thus giving congressional force to the original interpretation of the Sears and Conipco rule-that it does not apply to unpatented articles held in sccrecy. S. 643, 92d Cong., Ist Sess. (197I), would provide, in pertinent part, as follows:

35 U.S.C. \& $301-$

Preservation of Other Rights. This tịtle shall not be construed to pre-empt, or 


\section{Effect Upon the Industrial Espionage Privacy Remedy}

The combined effect of Sears, Compco, and Lear, of course, raises serious questions regarding the advocacy of a corporate right of privacy as an industrial espionage remedy. Especially is this apparent in light of the Christopher court's position that a violation of the commercial right of privacy was one form of improper discovery under the traditional trade secret doctrine. ${ }^{210}$ The critical inquiry is whether the corporate right of privacy is a distinct cause of action or simply another aspect of trade secret law subject to the vicissitudes of patent policy preemption, and hence of little consolation to the victims of industrial espionage.

Given the recent interpretation of the scope of federal patent policy preemption ${ }^{211}$ and the propensity of contemporary courts to favor the free dissemination and use of non-patented information, ${ }^{212}$ it is not entirely unforeseeable that the scope of preemption may truncate the common law trade secret doctrine. The harshness of such a result may, however, be prevented by several factors which could make the actual scope of preemption largely a matter of academic interest to the industrial espionage victim. The first is that Lear is likely to be restrictively construed, as were Sears and Compco, ${ }^{213}$ to

otherwise affect in any way, contractual or other rights or obligations, not in the nature of patent rights, imposed by State or Federal law on particular parties with regard to inventions or discoveries whether or not subject to this title.

Significantly, section 301 is omitted from an essentially similar bill introduced by Congressman Wilson, H. 4012, 92d Cong., 1st Sess. (1971). A bill similar to S. 643 was introduced in the 91st Congress, S. 2756, 91st Cong., 1st Sess. (1969), and received the endorsement of the American Bar Association. See ABA Section of Patent, Trademark \& Copyright Law ProceedINGS 140 (1970). An amendment to S. 2756 offered by Senator Scott would have made the congressional reversal of Lear apparent, and this amendment has also been offered in the $92 \mathrm{~d}$ Congress. S. Amend. No. 23, 92d Cong., 1st Sess. (1971), cited in 39 U.S.L.W. 2554 (Apr. 6, 1971). These proposals are discussed, and their effects analyzed, in Wetzel \& Niro, supra note 194, at $485-86$, where it is said that S. 2756 would delete from the patent laws what was never there before Sears and Compco. Regarding the bleak outlook for non-patented commercial secrets, it might, in any event, be recalled that the Supreme Court has previously taken positions substantially contrary to prior law only to find that its initial foray was too sweeping and that retreat was necessary. See, e.g., Thornhill v. Alabama, 310 U.S. 88 (1940). That case declared a broad union right to publicize labor disputes, a right which was thereafter significantly limited in Giboney v. Empire Storage \& Ice Co., 336 U.S. 490 (1949) and in Teamsters Local 695 v. Vogt, Inc., 354 U.S. 284 (1957).

210. 431 F.2d at 1015-16.

211. See notcs $167-209$ supra and accompanying text.

212. See note 84 supra and accompanying text.

213. See note I83 supra and accompanying text. 
preserve the trade secret law largely unaffected. ${ }^{214}$ Even if cases such as the district court opinion in Painton \& Co. prevail, however, federal patent preemption is nevertheless a matter of statutory, not constitutional preemption, and Congress retains the power to establish a federal trade secret policy independent of the patent laws and their preemptive character. ${ }^{215}$ Thus, before the trade secret law is entirely scrapped by construction or before the Court realizes the impact of its decision on industry, ${ }^{216}$ Congress may exercise its own initiative and establish a federal law of trade secrets not subject to patent law preemption thus mooting the question of the scope of preemption. ${ }^{217}$

Regardless of the future course of patent policy preemption, the right of privacy is not a matter of trade secret law, although it was so denominated in Christopher, ${ }^{218}$ but is rather derived from the law of torts and is not, therefore, subject to preemption by the patent laws. ${ }^{219}$ The corporate privacy right would, of course, punish the improper means of discovering trade secrets, but to label it as merely another form of trade secret relief is to misinterpret the right of privacy. A right of commercial privacy accords to the corporation a zone of secret existence not subject to the surveillance of its competitors. When that zone is compromised by the competitor, it is the intentional act of espionage which is punished, not the success or failure of the expedition. Even if no secrets are obtained, relief is still 69.

214. 45 N.Y.U.L. REv., supra note 176, at 393-95; 16 VILL. L. REV., supra note 208, at 568-

215. Bender 923; see 2 Callman $\S 53.2(\mathrm{~b})$.

216. It us been observed that the restrictive interpretation given Sears and Compco was a consequence of a recognition of the practical consequences that a broad preemption doctrine would cause in the market place, and in the application of the law of trade secrets. See 45 N.Y.U.L. REv., supra note 176, at 393.

217. Such a result has already been initiated. Senators McClellan and Scott have introduced in the $92 \mathrm{~d}$ Congress a bill whicb would give congressional sanction to a federal trade secret law. S. 647, 92d Cong., Ist Sess. (1971), would provide, in pertinent part, as follows:

$\S 43(a)$. Any person who shall engage in any act, trade practice, or course of conduct, in commerce, which-

...

(3) results or is likely to result in the wrongful disclosure or misappropriation of a trade secret or confidential information ....

A similar bill was unsuccessfully introduced in the 91 st Congress. S. 766,91 st Cong., 1st Sess. (1969). See Bender 923.

218. 431 F.2d at 1016-17.

219. The inapplicability of the Sears, Compco, and Lear preemption doctrine to common law causes of action is discussed by Judge Breitel, concurring, in American Harley Corp. v. Irvin Indus., Inc., 27 N.Y.2d 168, 174-82, 263 N.E.2d 552, 555-59, 315 N.Y.S.2d 129, 133-40 (1970). 
available. ${ }^{220}$ Since it is not the trade secrets as such which are protected, but rather the corporate "privacy sphere," the preemptive force of the patent laws should not effect the privacy protection. Whatever the declared policy bases of the patent laws, they can have only marginal applicability to the inviolateness of the corporate personality as it relates to the industrial espionage activities of competitors.

Although patent policy preemption casts a shadow over the scope of protection to be accorded non-patented information, that shadow is not itself grounds to deny the application of a corporate right of privacy to the industrial espionage victim.

\section{CONCLUSION}

The need for a corporate right of privacy as a remedy for the industrial espionage victim has been clearly espoused in both legislative analysis ${ }^{221}$ and judicial opinion. ${ }^{222}$ Supporting these legislative and judicial findings are the conclusions of those analysts who have seriously considered the present dilemma of the unprotected industrial espionage victim. ${ }^{223}$ But, notwithstanding this articulation of recognized need, the leading privacy commentators have mechanistically adhered to juristic consistency by rejecting the corporate privacy cause of action, ${ }^{224}$ although conceding that in some respects the corporation receives the same privacy rights and remedies as does the individual. ${ }^{225}$ To reject a corporate privacy right while

220. See note 137 supra and accompanying text.

221. Hearings on S. 928, at 610-11.

222. E.I. duPont deNemours \& Co. v. Christopher, 431 F.2d 1012 (5th Cir. 1970).

223. See note 105 supra and accompanying text.

224. Restatement (SeCOND) of Torts \$ 652J (Tent. Draft 13, 1967). The Restatement cites the same cases discussed and distinguished at notes 52-69 supra. Id., comment $c$, at 147 .

225. The Restatement provides as follows:

A corporation . . . has no personal right of privacy. . . . It has, however, a limited right to the eclusive [sic] use of its own name or identity . . . and it receives protection from the law of unfair competition. . . . To some limited extent this may afford it the same rights and remedies as those to which a private individual is entitled funder the law of privaey]. . . ."Id. at 146.

This language is similar to that in Fleck Bros. Co. v. Sullivan, 385 F.2d 223 (7th Cir. I967), where plaintiff corporation brought action alleging libel and an invasion of its right of privacy for defendant credit information company's use of its name. The court did not pass on the privacy claim, but commented that if the libel ground were upheld the privaey claim would also be satisfied. Id. at 225 .

The language of the Tentative Draft and Fleck Bros., thus, indicates the curious position of refusing to allow a corporation directly the proteetion it may obtain indirectly. This perhaps 
conceding that corporate privacy interests may yet be protected is, at the least, hypocritical. To invest corporations periodically with the benefits of a privacy right, but to stubbornly reject absolute recognition because of unrelenting adherence to unnecessarily broad contrary precedent, ignores the traditional common law adaptation to changing economic and social circumstances. ${ }^{226}$

Whenever courts are presented with a new right or remedy, or the extension of an old one into a new area, the instinctive reaction is to reject the assertion and refrain from unleashing a cascade of vexatious litigation. The corporate right of privacy is, of course, open to such objection, which predictably met the advocation of the personal privacy right decades ago. ${ }^{227}$ Such an argument should not, however,

indicates the strained position in which courts find themselves when they desire to adhere to a firm line of precedent - that a corporation has no right of privacy-but are confronted with a situation which demands relief. Such a strained position would likely indicate that the next step will be the recognition of the corporate privacy right. This would certainly be one means of reconciling Christopher, discussed at notes 96-104, 158-63 supra, and accompanying text, with the previously firm line of authority holding that a corporation had no privacy rights.

226. "Political, social, and economic changes entail the recognition of new rights, and the common law, in its eternal youth, grows to meet the demands of society." Warren \& Brandeis 193. See also Nizer, supra note 31 , at $526,559$.

227. Roberson v. Rochester Folding Box Co., 171 N.Y. 535, 545, 64 N.E. 442, 443 (1902); Lisle, The Right of Privacy (A Contra View), 19 Ky. L.J. 137, 142 (1931).

A legitimate question might be raised regarding the potential scope of the corporate privacy remedy: against what will it be directed? While a complete response is difficult because the limits of the remedy will depend largely upon the means employed by future industrial espionage pirates, a test may be fashioned to provide some indication of the parameters of the doctrine. One test that might be applied would provide that the corporate right of privacy remedy will punish conduct which violates the privacy sphere of the corporation, and which is unanticipated, undetectable, or unpreventable. See E.I. duPont deNemours \& Co. v. Christopher, 431 F.2d 1012, 1016-17 (5th Cir. 1970).

With this test as a guide, it is appropriate to explorc briefly some of the effects of the right of privacy on current industrial espionage practices. With regard to most forms of electronic surveillance, for example, the privacy remedy would, under this test be relevant, since the detection and prevention of eavesdropping may be essentially impossible. A similar result might be anticipated with regard to the intentional placing of spies in a competitor's plant. The difficult cases, however, will involve situations where present remedies are inadequate, as, for example, the predicament of an employer whose employee joins a competiting corporation which subsequently begins production of what had theretofore been the employer's trade secret product. $1 t$ has already been noted that the judicial remedy in this area accords scant protection to the former employer. See notes $83-90$ \& 110 supra and accompanying text. Will a privacy remedy prevail? Under the Christopher test discussed above, it would probably not. This is a type of competitor activity which can be anticipated, is reasonably detectable, and preventable. See Harding, supra note 94, at 402-04. Moreover, there are significant policy decisions implicitly made by courts which would delimit privacy relief even if the privacy remedy were to apply. See note 84 supra and accompanying text.

Because any corporate right of privacy claim is likely to be accompanied by untold factual 
impede the adoption of the corporate privacy remedy. The courts have had no difficulty ferreting legitimate from vacuous claims of individual privacy invasion and should be similarly successful in the corporate context. Objection might also be made on the ground that once recognized the application of the corporate right of privacy would uncontrollably expand beyond industrial espionage into other areas where corporate privacy protection is either unnecessary or undesirable. Over the years, however, aspects of corporate privacy have been both granted and denied, evidencing the judicial ability to segregate claims. This flexibility serves both to rebut objection to, and indicate the present vitality of, the corporate privacy right even beyond the industrial espionage context. Thus, the corporation is allowed privacy recovery for the commercial use of its name or reputation, ${ }^{228}$ for the unconscionable tactics of the credit reporting bureaus, ${ }^{229}$ and for the installation of electronic surveillance devices upon its premises, ${ }^{230}$ but is denied an element of privacy when its claim to the privilege against self-incrimination is rejected..$^{231}$

The evolutionary process culminating in the present recognition of a corporate right of privacy, although grudging, essentially typifies the common law process. The need for privacy protection in the industrial espionage context having been made apparent, a corporate right of privacy has been recognized. Because this new corporate right is derivative of tort and not trade secret law, it is immune from possible federal patent policy preemption. The industrial espionage victim now has only to prove the act of surveillance to premise his recovery, with actual damages and coincident scienter constituting the bases of special and punitive damage awards. Potential and present industrial espionage piratcs are now forewarned that the risks and liabilities of espionage tactics have risen to the point that it may no longer be such a "good gamble" to undertake a surveillance campaign against one's competitors. ${ }^{232}$

nuances, and because it is simply beyond the scope of this comment, an exhaustive discussion of the future application of the doctrine is not attempted here. Once courts take notice of the privacy remedy as an existing means of protecting corporations, they should have little difficulty segregating appropriate right of privacy claims.

228. See, e.g., Utah Code Ann. § 76-4-9 (Supp. 1968).

229. Fleck Bros. Co. v. Sullivan, 385 F.2d 223, 225 (7th Cir. 1967). The court noted that privacy protection could be had, although the name of the relief might be different.

230. E.I. duPont deNemours \& Co. v. Christopher, 431 F.2d 1012 (5th Cir. 1970); Hearings on $S .928$ 610-11. See also notes 150-57 supra.

231. United States v. White, 322 U.S. 694, 699 (1942). See note 55 supra.

232. See Milgrim $\S 5.05$, at 75 (Supp. 1971). Why industrial expionage has heretofore been a "good gamble" is discussed at notes $91-104$ supra and accompanying text. 
